\title{
DEVELOPING AN EVALUATION TOOL FOR GREEN ROOF TYPOLOGIES
}

\author{
By \\ Cameron Laidlaw \\ Bachelor of Commerce \\ University of Guelph, 2013
}

\begin{abstract}
An MRP presented to Ryerson University
in partial fulfillment for the degree of

Master of Building Science in the

Department of Architectural Science
\end{abstract}

Toronto, Ontario, Canada, 2015

(C)Cameron Laidlaw, 2015 


\section{AUTHOR'S DECLARATION}

I hereby declare that I am the sole author of this MRP. This is a true copy of the MRP, including any required final revisions.

I authorize Ryerson University to lend this MRP to other institutions or individuals for the purpose of scholarly research.

I further authorize Ryerson University to reproduce this MRP by photocopying or by other means, in total or in part, at the request of other institutions or individuals for the purpose of scholarly research.

I understand that my MRP may be made electronically available to the public. 


\begin{abstract}
Developing an Evaluation Tool for Green Roof Typologies. M.B.Sc., Cameron Laidlaw, Master of Building Science, Ryerson University.

Green roofs possess the potential to provide a plethora of benefits in the urban environment. The variability among the green roof typologies (intensive, extensive, and agriculture) leads to different benefits when one system is selected over another. By the collection and analyzing of metadata, an evaluation tool is developed to assist green roof designers to meet the goals of their specific project. Included criteria for evaluation are: water runoff quantity, water runoff quality, maintenance, amenity, and irrigation. The evaluation tool is designed to be compartmentalized, with each criteria treated independently, allowing further expansion, alteration, or refinement of the tool in the future.
\end{abstract}


AUTHOR'S DECLARATION ……………………………………………………………...... ii

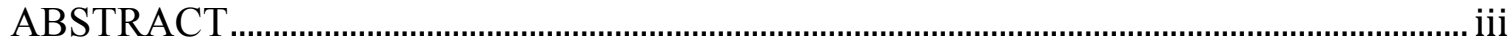

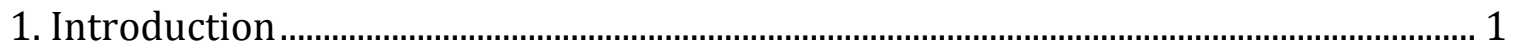

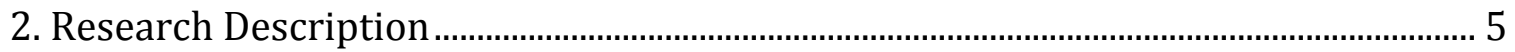

2.1 Scope

2.2 Methodology \& Approach........................................................................................ 6

2.2.1 Literature Review Methodology ……………………………………………….... 7

2.2.2 Evaluation tool Development Methodology …………………………………... 8

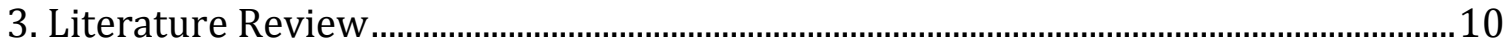

3.1 Initial Criteria Evaluation .....................................................................................10

3.1.1 Water Runoff Quantity .......................................................................................10

3.1.2 Water Runoff Quality …………………………………………………………....10

3.1.3 Urban Heat Island..............................................................................................11

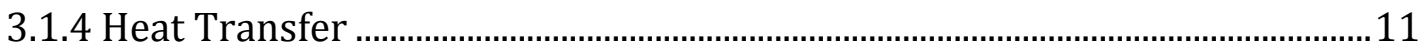

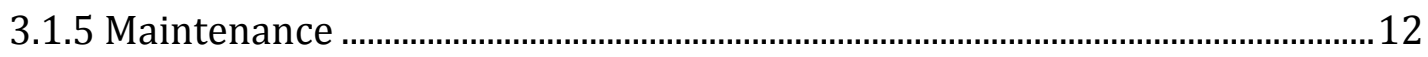

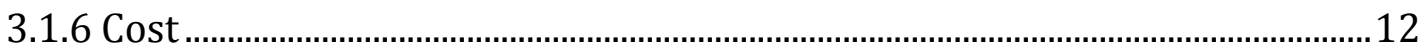

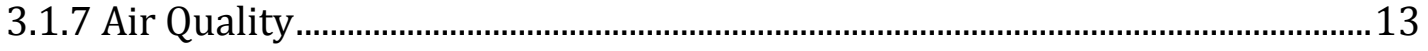

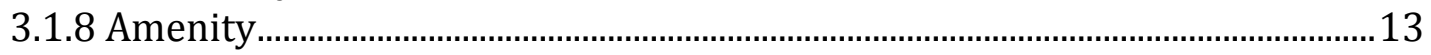

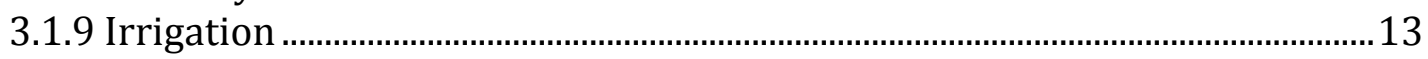

3.1.10 Selected Criteria ...................................................................................................... 14

3.2 Criteria Literature Review ……………………….....................................................15

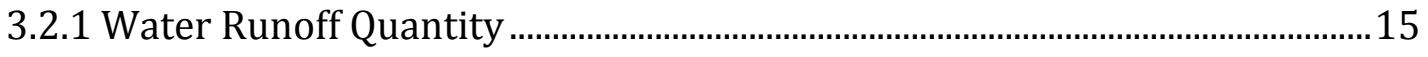

3.2.2 Water Runoff Quality …………………………………………………………....19

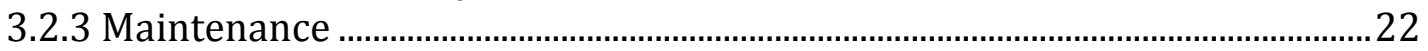

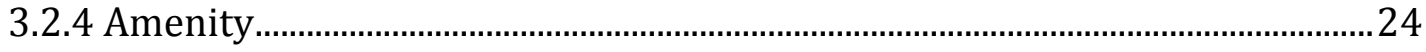

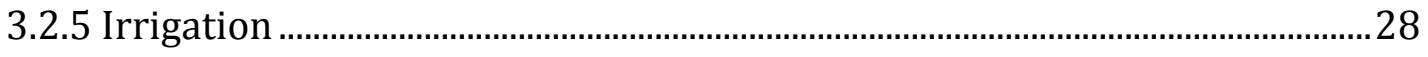

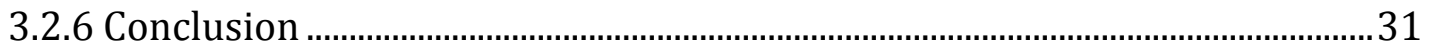

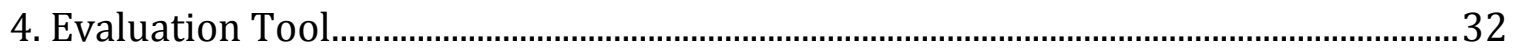

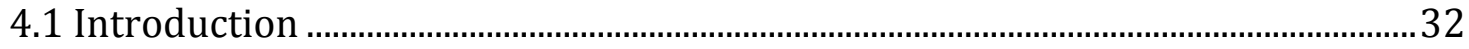

4.1.1 Terminology …………………………………………………………………33

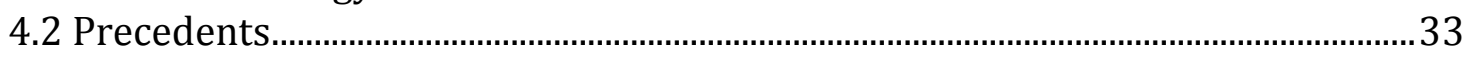

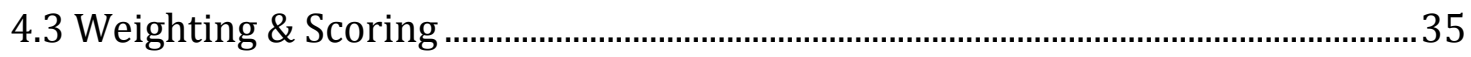

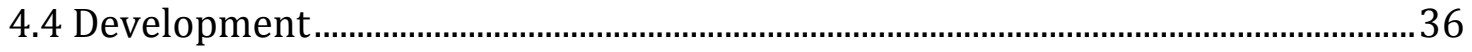

4.4.1 Storm Water Runoff Quantity .............................................................................36

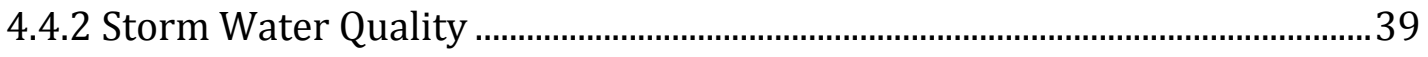

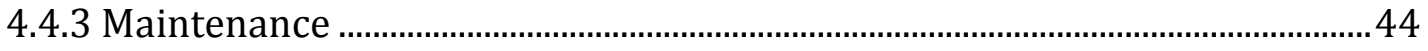

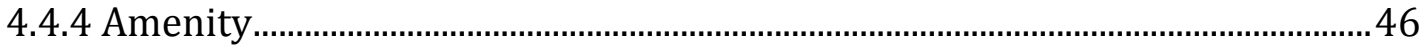

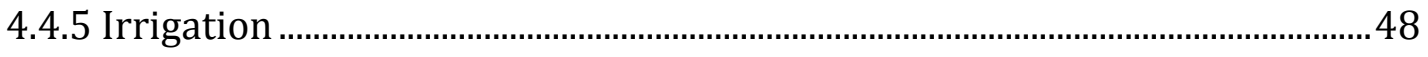

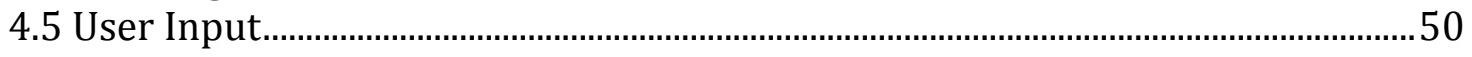

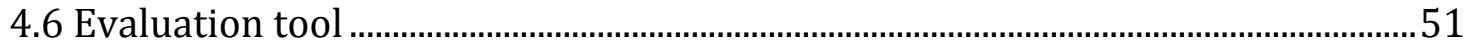

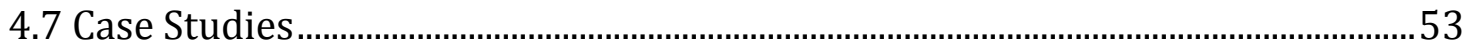

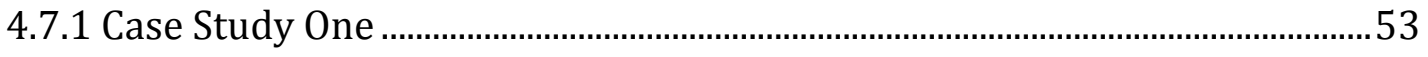

4.7.2 Case Study 2 ………………………………………………………………...56

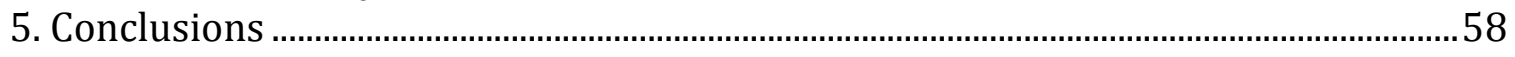

5.1 Overall Conclusions.................................................................................................58

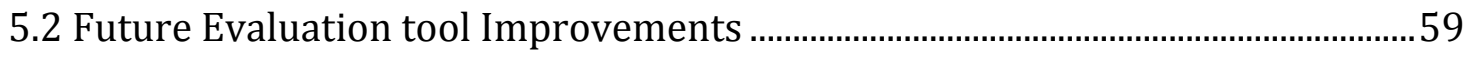


References

Appendix A: Keywords/Search Terms.

Table 1, Toronto Green Roof Coverage Requirements (City of Toronto, 2013) ............ 3

Table 2, Summary of Storm Water Runoff Benefits Reported ...........................................19

Table 3, Relationship Between Substrate Depth and Runoff to be Used in the Evaluation Tool...

Table 4, Evaluation Tool Point Allocation for Different Substrate Depths.....................39

Table 5, Evaluation Tool Point Allocation for Different Substrate Depths......................41

Table 6, Evaluation Tool Point Allocation for Different Leaf Area Indices.......................44

Table 7, Evaluation Tool Point Allocation for Different Labour Profiles .........................46

Table 8, Evaluation Tool Point Allocation for Different Typologies...................................47

Table 9, Evaluation Tool Point Allocation for Accessibility .................................................47

Table 10, Evaluation Tool Point Allocation for Food Production.......................................48

Table 11, Evaluation Tool Point Allocation for Different Watering Schemes ...............50

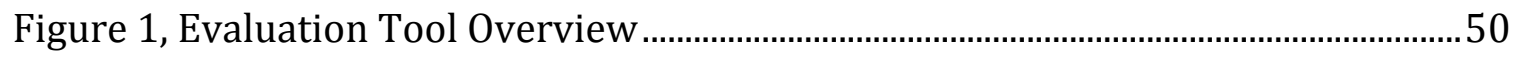

Figure 2, Case Study 1 Weightings ........................................................................................51

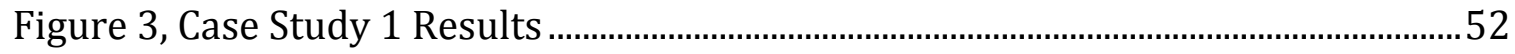

Figure 4, Case Study 2 Weightings .......................................................................................53

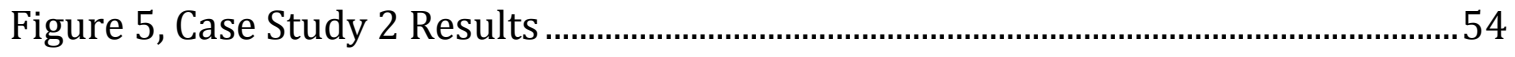

Figure 5, Case Study 2 Revised Results................................................................................55 


\section{Introduction}

Throughout North America, green roofs continue to grow in popularity. This is a result of the host of benefits that they provide, including reduction of the urban heat island, increased amenity, storm water runoff reduction, and reduced heat transfer. These benefits are present to different degrees from project to project, and result from the design of the green roof, which is based on a variety of parameters including weight restrictions, designer and client preferences, and statutory requirements.

There are two basic types of green roof systems: extensive and intensive. Various definitions exist, with no universally agreed upon point where a system changes from being one to another. Extensive systems utilize a thin substrate, with this layer typically being defined as 100-150 mm (4-6 in) or less in depth (Berdntsson, 2010, Wong, Tan, \& Chen, 2007). Intensive systems are generally classified by having substrates that are $150 \mathrm{~mm}$ (6 in) in depth or greater (Berndtsson, 2010, Mentens, Raes, \& Hermy, 2006). This deeper substrate allows for a wider range of vegetation to be planted, and can include shrubs and trees that require deeper roots to thrive. There is also a third typology, which can be viewed as a sub-type of the intensive system: rooftop agriculture. This typology is different from a system whose plants are selected for coverage or aesthetic reasons - plant species are selected based on their ability to yield something edible. Generally, this includes herbs and vegetables, along with some fruits that grow on smaller plants, such as tomatoes. The planting of crops means that some space in a rooftop agriculture project must be left unplanted for access to crops, decreasing the overall plant coverage. Irrigation is also generally required, as crops require more water than other green roof plant species like sedum. Although rooftop agriculture can be seen as a sub-type of the intensive typology, the term "intensive" in this work is used only in reference to non-food roofs, such as those with large vegetation like trees and shrubs.

The thin substrate profile of extensive systems limits the variety of vegetation that can be used, as tall species, which generally require deeper roots, cannot grow well under these 
conditions. Extensive systems instead utilize low-growing, hardy plants, with sedum being the most popular due to its drought tolerance, hardiness, ability to flourish across many climate zones, and good ground coverage (Getter \& Rowe, 2008, Monterusso, Rowe, \& Rugh, 2005, VanWoert, Rowe, Andresen, Rugh, \& Xiao, 2005b). The weight of extensive systems is also lower, primarily due to the thinner substrate. This makes extensive systems applicable to a wider range of buildings, as a building's existing structure may not support the greater loads imposed by an intensive or agriculture system. Due to the lower structural requirements, thinner substrate depth, and use of hardy plants, extensive systems are also less costly to install. The combination of these factors has led extensive systems to be by far the most popular type of system, with nearly $500 \%$ more square feet of extensive green roof installed in 2014 than intensive (Green Roofs for Healthy Cities, 2015).

The impetus for municipalities to encourage green roof development varies by location and the needs of the municipality, including encouraging biodiversity, air quality improvement, and energy savings among others (Canada Mortgage and Housing Corporation, 2006). An important factor for Toronto is the use of green roofs as a means of reducing storm water runoff. As urban centres intensify, the number of impervious surfaces is ever increasing. This leads to higher quantities and speeds of storm water discharge, which results in pollution of lakes and streams connected to outlets of the storm water system (Bucheli, Müller, Heberle, \& Schwarzenbach, 1998, Mentens et al. 2006, Teemusk \& Mander, 2009). By implementing measures to reduce or delay discharge into city storm water systems, existing storm water infrastructure is more able to handle the stress of rain events. Given that rooftops make up $30-50 \%$ of all impermeable surfaces in urban areas (Carter \& Jackson, 2007, Dunnett \& Kingsbury, 2004), and up to $85 \%$ in downtown and commercial areas (Carter \& Jackson, 2007), the use of green roofs is a natural fit to help alleviate this issue. Green roof substrate provides storm water detention and retention, slowing the water's movement into the storm water management system. In lighter rain events, the capacity of the green roof can be sufficient to eliminate storm water runoff altogether. In heavier rain events, storm water 
discharge from the roof can be delayed by up to 10 minutes (Getter, Rowe, \& Andresen, 2007, VanWoert, Rowe, Andresen, Rugh, Fernandez, Xiao, 2005a).

In 2009, the City of Toronto implemented a bylaw that requires green roofs to be built on all new construction over $2000 \mathrm{~m}^{2}$ in gross floor area, making it the first municipality in North America to do so (Aster \& Mecklinger, 2010). This bylaw put the city at the forefront of this emerging trend. According to the bylaw, every new building or building addition with a gross floor area greater than $2,000 \mathrm{~m}^{2}\left(21,500 \mathrm{ft}^{2}\right)$ must include a green roof. The gross floor area dictates what percentage of the available roof area be constructed as a green roof. Within the bylaw there is also a stipulation that the planted area reach $80 \%$ coverage within three years of construction (City of Toronto, 2013). The requirements are shown in Table 1, below. These requirements limit the potential number of urban agriculture projects, as crops are generally annual plants that must be planted anew each year.

Table 1, Toronto Green Roof Coverage Requirements (City of Toronto, 2013)

\begin{tabular}{|l|l|}
\hline \multicolumn{1}{|c|}{$\begin{array}{c}\text { Gross Floor Area (Size of } \\
\text { Building) }\end{array}$} & \multicolumn{1}{|c|}{$\begin{array}{c}\text { Coverage of Available Roof Space (Size of Green } \\
\text { Roof) }\end{array}$} \\
\hline $2,000-4,999 \mathrm{~m}^{2}$ & $20 \%$ \\
\hline $5,000-9,999 \mathrm{~m}^{2}$ & $30 \%$ \\
\hline $10,000-14,999 \mathrm{~m}^{2}$ & $40 \%$ \\
\hline $15,000-19,999 \mathrm{~m}^{2}$ & $50 \%$ \\
\hline $20,000 \mathrm{~m}^{2}$ or greater & $60 \%$ \\
\hline
\end{tabular}

Although the popularity of green roofs has continued to grow, there is, at present, no concrete method of evaluation or comparison among the multiple types that are available. Much research has been carried out investigating green roofs, but these works focus on one issue or a select subset of the same. The result is that there is no existing work bringing together information in a way that can be easily parsed; it is cumbersome and 
labour-intensive for interested parties to obtain a granular understanding of the performance benefits and drawbacks of each design choice or green roof typology.

This work attempts to undertake a holistic examination of green roof performance, identifying the most important factors influencing performance, particularly those that vary to the greatest degree between each of the three typologies. The examination is undertaken with the goal of establishing a level of understanding that allows for the creation of an evaluation tool for assessing green roof typologies. The creation of such a tool serves two purposes: it provides easily digestible information for those seeking knowledge on a particular aspect of green roofs, and it will allow users to understand the impact that their choices have on a particular green roof project, and provide a justification for making one choice over another. By bringing together information from a variety of sources and in a variety of categories, users will be able to make better, more informed choices. A separate benefit that emerged over the course of this work was to identify the lack of complete knowledge in some areas of green roof research. Some topics have, to this point, received more research attention than others, particularly in the realm of rooftop agriculture. This is largely the result of specific aspects of green roofs being easier to design experiments for (such as storm water quantity), and certain typologies being more popular than others (such as extensive systems). The evaluation tool that has been developed is intended as a work that can be added to as more knowledge becomes available, growing and adapting with the overall body of knowledge. 


\section{Research Description}

This paper investigates the performance differences between extensive, intensive, and urban agriculture green roof typologies. Through use of metadata gathered from existing literature, an evaluation tool has been developed that allows users to evaluate the potential performance of a planned green roof. This tool will guide the decision making process of future green roof projects, allowing green roof designers to investigate the performance differences that will be brought about by selecting one strategy or system over another. Particular focus is given to the differences in storm water quantity and quality, maintenance, amenity, and irrigation impacts and differences between the typologies. The aim of this work is to investigate the performance differences between each system determine whether significant differences exist between each typology, with the goal of advancing the understanding of the performance of each typology as it compares to the others. The questions that form the core of this research are as follows:

1. What are the parameters by which the performance of intensive, extensive, and urban agricultural green roofs can be compared?

2. What method can be used to carry out a comparison between green roof typologies to determine the level to which they meet the performance goals of the selected criteria?

These questions are used as the driving force behind the development of the evaluation tool presented in this paper. The evaluation tool has been developed to answer these questions and to present the collated information in a format that can be used with little detailed technical information. Additionally, the tool has been designed such that those without expert-level knowledge about green roofs can use it. Such a tool is helpful to provide a higher level understanding of the impact of each green roof typology for the user's specific situation. The evaluation tool is also applied to case studies to showcase the process and results of using the completed evaluation tool. 


\subsection{Scope}

This evaluation tool has been designed to evaluate new green roof projects on buildings in Toronto. The small geographic area allows for the elimination of climate as a factor; all locations within the bounds of the city of Toronto experience largely similar climatic conditions throughout the year. This evaluation tool may, as described in this paper, be applied to other projects in similar climate zones, but it has not been designed to work as such. Subsequent works could either expand this evaluation tool to include consideration of other climates, or reorient the evaluation tool to apply to another climate zone specifically.

The criteria that will be most significantly affected by a change of location is water runoff quantity. Toronto has a cold-humid climate (ASHRAE, 2008), indicating a high number of heating degree days and a high level of precipitation. Other climate zones will have more or less evapotranspiration and precipitation, and thus will perform differently than as described in Toronto. To utilize the evaluation tool in another location, the formula discussed in Section 4.4.1 may be used, inputting the precipitation experienced at the location in question. Based on the information available in the literature, this is the category that would be most significantly impacted. However, if a user has or finds information indicating, for example, that green roofs offer a greater property value increase in their location than that discussed here, that section could be adjusted in response. This evaluation tool has been developed in a compartmentalized fashion, with no interaction between individual criteria. This allows for each section to be treated independently and adjusted without adjusting the entire evaluation tool.

\subsection{Methodology \& Approach}

This project consists of two major portions: (1) a literature review to establish criteria for the evaluation tool, and (2) creation of the evaluation tool itself through use of the gathered metadata. Through examining a wide variety of existing published research, the aim was to identify the criteria that showed both the largest performance differences 
between different green roof typologies and also those that are seen as most important to researchers, industry, and policymakers.

\subsubsection{Literature Review Methodology}

The literature review consisted of two parts: criteria determination, and data synthesis. The criteria determination entailed the collection of published data to help inform the structure evaluation tool. This information was then used later to develop the evaluation tool itself. Due to the scope and timeline of this project, not all identified criteria could be included in the evaluation tool. To address this, a method for selecting a subset of criteria was required.

A literature review was carried out with the goal of determining the most relevant criteria for use in the evaluation tool. The literature review was based on the method used by Blank et al. (2013), in which papers were found using a group of keywords/terms with modifiers. Papers were sourced initially solely through the Ryerson University Library. The search centered around the terms "intensive green roof," "extensive green roof," and "green roof agriculture," corresponding with each of the typologies being investigated. Additional modifiers were used on these phrases to locate papers about a specific topic if initial results did not yield the required results. For example, "green roof agriculture maintenance" was one such term. These terms were not set beforehand, but evolved based on the literature review. As terms were discovered through the investigation, additional modifier terms were added to the search. A full list of keywords and modifiers used is included in Appendix A.

From the papers yielded by these searches additional sources were located by examining the references used in the papers. Sources that were found to be available through the Ryerson Library were then also included. During this portion of the literature review additional conference papers were also sourced from outside the university's library. This method continued until an exhaustive list had been compiled.

The aspects of green roofs that each paper investigated were noted, and a list of potential evaluation tool criteria was built. For a paper to be included in this analysis, it needed to 
address, either through primary research or analysis of other works, one or more potential criteria. The resulting criteria included for investigation were:

1. Water runoff quantity

2. Water runoff quality

3. Urban heat island

4. Heat transfer

5. Maintenance

6. Cost

7. Air Quality

8. Amenity

9. Irrigation

Each paper was entered into a spreadsheet to determine the number of papers that investigated each topic. If a paper addressed a criterion, it was marked in the spreadsheet with a " 1. " If that criterion was not addressed, it was marked with a "0." This method yielded a total of 42 papers that addressed at least one of the criteria listed above. The full table of all papers is included in Appendix B.

\subsubsection{Evaluation tool Development Methodology}

To develop the evaluation tool, the metadata gathered through the literature review was analyzed to determine which criteria showed performance differences between each of the green roof typologies. The criteria that displayed the greatest potential for variation were selected for use in the evaluation tool. This process is discussed in depth in Section 3.1 .

For each of the selected criteria, the gathered metadata was analyzed in an attempt to establish a means of comparison, and, where possible, to come up with quantifiable figures. Each criteria was broken down into its constituent variables, based on the information in the literature about what aspect of a green roof's design impacts its performance in that category It was not possible to develop quantifiable figures for all variables due to lack of published data, namely specific variables within the storm water 
quality, amenity, and irrigation criteria. These variables are discussed in depth in Sections 4.4.2, 4.4.4, and 4.4.5, respectively. For these criteria the existing data was used to draw general conclusions. As more research on green roofs is carried out, it will be possible to refine these areas and offer more granular and concrete metrics.

Where quantifiable figures were used, points were awarded on the basis of performance, with the best performing option receiving full points. Other options were awarded points based on their performance relative to the best option. This required a decision as to what the 'best' option would be. Generally, this was clear, as it was straightforward to understand the logic behind what most users would consider to be the 'best' performance. However, there are edge cases where a user might be approaching a particular variable from a different perspective and thus disagree with how points have been allotted. The evaluation tool as developed in this work is not built to allow the reassigning of points, as they are based on the literature review that has been undertaken. Instead, it is suggested that users alter the weighting of a category to omit a particular variable from the assessment. The decision-making behind each point assignment is discussed in Section 4.4. More detail on weighting is available in Section 4.3. 


\section{Literature Review}

\subsection{Initial Criteria Evaluation}

Each criterion listed in Section 2.2.1 was investigated to establish whether there was a significant difference among green roof typologies. The goal was to collect metadata, which could then be further analyzed to identify trends within the data. This would allow for conclusions and judgements about performance to be made with a factual basis. Following is a summary of the overall result of each criterion's investigation and discussion of the suitability of the appropriateness of use in the evaluation tool.

\subsubsection{Water Runoff Quantity}

Water runoff quantity has historically been the driving force behind municipalities' adoption of green roofs. As cities intensify and green spaces are increasingly paved over, storm water runoff quantities and speeds are increased as water is directed into the storm water sewer system (Bucheli et al. 1998, Mentens et al. 2006). To counter this, cities such as Toronto and Portland have created green roof incentive programs that encourage green roofs for the purpose of detaining or retaining storm water. This policy focus has lead to large amounts of research on the effects of green roofs on storm water runoff quantities to evaluate the efficacy of green roofs in meeting this objective. For these reasons, water runoff quantity was chosen to be included in the analysis.

\subsubsection{Water Runoff Quality}

This criterion is of particular importance for this evaluation tool, as farms generally require the use of fertilizer, which introduce additional substances to the growth media. These elements can cause elevated levels of nutrients in roof effluent that have the potential to cause eutrophication in receiving bodies of water (Whittinghill \& Rowe, 2012). Nutrient loading is highly variable based on the type of growth media, fertilizer type, roof age, and plant coverage.

A key work in this area is by Berdntsson, Bengtsson, \& Jinno (2009), who investigated performance differences between intensive and extensive green roofs. Results indicated that the effluent coming off of intensive roofs displays lower quantities of contaminants. 
This trend held for two of the major components of fertilizer: nitrogen and phosphorus. Potassium, the third building block, was not significantly reduced by either roof. Heavy metal concentrations were not found to be impacted by either roof, indicating that, while the roofs do not reduce these concentrations, they also do not contribute to their presence in effluent. Rainwater entering the intensive roof was initially acidic, with a $\mathrm{pH}$ of 5 . The effluent showed significantly reduced acidity, with an outgoing $\mathrm{pH}$ of 7.5 , a value less harmful to receiving bodies of water. As a result, this criterion was selected for use in the evaluation tool, as each of the typologies has significantly differing impact on that criterion.

\subsubsection{Urban Heat Island}

The urban heat island effects of green roofs were found to be based on the presence of plants yielding a higher albedo than typical city hardscapes (Coutts, Daly, Beringer, \& Tapper, 2013, Gagliano, Detommaso, Nocera, \& Evola, 2015, Getter \& Rowe, 2006). In

this respect, all green roof systems result in good performance, making this a poor criteria for comparison. There is some difference among plants with varied leaf area indices, but a lack of discrete data on each typology makes a good comparison between each of the typologies difficult. As a result, this criteria is not included for use in the evaluation tool.

\subsubsection{Heat Transfer}

The finding from the literature is that green roofs offer the greatest benefit to short buildings and those with little existing roof insulation. Tall buildings benefit less from a heat transfer point of view due to their roof being a smaller percentage of their total surface area than short and wide buildings. Buildings with little or no roof insulation benefit more from the addition of green roofs due to the relatively high increase in insulation from the addition of the green roof substrate (Gagliano et al. 2015, Wong, Tan, \& Chen, 2007, Niachou, Papakonstantinou, Santamouris, Tsangrassoulis, Mihalakakou, 2001). In Ontario, roof insulation is required by both SB-10 and SB-12, supplementary standards to the Building Code that set out energy efficiency requirements for buildings in the province. Additionally, Toronto is a city undergoing rapid development and intensification. High-rise projects, particularly residential projects, are a significant 
portion of the real estate market, and this trend is set to continue (City of Toronto, 2015b, 2015c). These high rise buildings have very little roof area relative to their overall area. Taking these factors into account, heat transfer was not selected as a criterion to be included in the evaluation tool.

\subsubsection{Maintenance}

Maintenance varies significantly between each of the considered typologies. Wong, Wong, Tay, Ong, \& Sia (2003) found that intensive roofs require between 1.5 and 2 times as much maintenance in monetary terms over extensive roofs, depending on the species used. Larger species such as trees were more expensive, with smaller species such as shrubs found to be less expensive.

A key difference between typical extensive green roofs and rooftop urban agriculture roofs is the requirement of continued human inputs. Extensive green roofs are generally designed to be nearly self-sufficient, generally undergoing annual or twice-yearly inspections for weeding and ensuring the integrity of waterproofing and drainage systems. Rooftop farms, however, require continued labour over the growing season. This generally consists of a mix of a small number of paid positions supplemented with volunteers (Proksch, 2011). Higher person-hour requirements result in higher overall costs for these systems. As this is one of the most visible differences between rooftop farms and extensive green roofs, it is important that this criterion be included in the evaluation tool.

\subsubsection{Cost}

Green roofs are, in the short term, more expensive than traditional roofs. This results chiefly from higher construction costs upfront, including the cost of the materials themselves, the possible need for structural upgrades to hold greater weight, infrastructure upgrades to service the roof, and increased access is the cause. In the long term, however, green roofs are generally understood to be economical, as they increase the lifespan of the roof assembly, resulting in a lower cost when evaluated on a timespan of decades (Veisten et al. 2012, Wong et al. 2003). Existing rooftop farms showcase that 
the price of a farmed green roof is not necessarily higher than that of a standard extensive green roof, with material costs falling in the $\sim \$ 50-100 / \mathrm{m}^{2}\left(\$ 5-10 / \mathrm{ft}^{2}\right)$ range (Proksch, 2011). As a result, this criteria was not selected for further comparison.

\subsubsection{Air Quality}

Studies cited by Banting et al. (2005) discuss indirect benefits such as the reduction of cooling, and thus, energy usage and pollution produced by power plants. They also discuss the potential for grass to remove particulate matter from the air by trapping it on its leaves. Little detailed data is available, making comparison between green roof typologies difficult. The scale of this benefit also tends to be small (Bianchini \& Hewage, 2012); Getter, Rowe, Robertson, Cregg, \& Andresen (2009) suggest that green roofs offer a "small but significant potential for sequestering carbon in urban environments" ( $p$. 7569). This criteria was not selected for the evaluation tool as a result.

\subsubsection{Amenity}

Existing literature generally quantifies amenity by translation to a dollar value, representing people's willingness to pay for a feature - in this case, a green roof. To do this, hedonic regression is typically used. Through the use of hedonic models, green roofs are found to contribute to higher rents and sale prices (Ichihara \& Cohen, 2010, Knut et al. 2012). Other works utilize more indirect methods, substituting the known value that purchasers place on parks and applying a similar value to green roofs (Peck et al. 1999, Tomalty \& Komorowski, 2010). Different green roof typologies are found to contribute varyingly to amenity, with intensive and extensive conferring greater value than agricultural roofs, indicating that this is a good criteria for inclusion.

\subsubsection{Irrigation}

Water requirements among plant species are highly varied. Many of the common varieties of plants used on extensive rooftops are of the sedum genus. These plants are characterised by high drought tolerance and low substrate requirements (Monterusso, Rowe, \& Rugh, 2005). This has led to wide adoption, as sedum roofs can be light and generally do not require supplemental irrigation. Intensive systems generally do require 
supplemental irrigation, as taller, leafier plants are often used. Water-hungry crops such as tomatoes, peas, and beans can exacerbate this need (Brouwer \& Heibloem, 1986). The wide variance between roof types here indicates that it is a highly relevant criterion. When considered in addition to the goal of reducing storm water runoff, this criterion becomes even more important, and was thus included in further examination.

\subsubsection{Selected Criteria}

Based on the literature reviewed and discussed above, five criteria have been selected. These criteria represent those aspects of green roof performance that display significant performance differences between each of the three typologies. This offers an answer to the first research question stated in Section 2: "What are the parameters by which the performance of intensive, extensive, and urban agricultural green roofs can be compared?" This question has been answered within the scope discussed in Section 2.1, as not all identified criteria could be investigated during the course of this work. This being the case, the selection process was instrumental in developing a strong set of criteria that offered the largest impact within the constraints of this work. Although each of the 9 criteria discussed are relevant to the performance of green roofs, the five that were selected have been found to be the most impactful and differentiating.

Therefore, the list of criteria for inclusion in the evaluation tool is:

1. Water Runoff Quantity

2. Water Runoff Quality

3. Maintenance

4. Amenity

5. Irrigation 


\subsection{Criteria Literature Review}

Following is a more thorough discussion of each selected criteria, and a review of the literature relevant to each.

\subsubsection{Water Runoff Quantity}

A chief driver behind the adoption of green roofs has been municipalities' need to manage storm water. Toronto is a rapidly intensifying city, and as the proportion of impervious surfaces throughout the city increases, storm water has fewer opportunities to discharge into the ground. This means that it is instead funnelled to the city's aging storm water system, which was largely constructed more than 50 years ago and is thus not equipped for the modern demands of the city (City of Toronto, 2015a). In some neighbourhoods combined sewers are still used, which results in mixing of sewage and storm water, all of which must then be sent to a treatment plant before being discharged. During heavy rain events treatment plants can become overloaded, resulting in untreated mixed water overflowing into streams, rivers, and Lake Ontario. Green roofs help address this issue through reducing or eliminating some of the storm water that would otherwise make its way into the sewer system. This reduces the load on the system as a whole.

The effects of green roofs on storm water runoff quantity have been investigated to the greatest extent, as represented by the number of publications addressing the subject. Drawing direct comparisons from one study to another is difficult, as many variables affect the performance of a green roof with respect to its runoff, including study period, location, vegetation type, and substrate depth, among others. However, similar trends are observed in the studies investigated.

A study by VanWoert et al. (2005a), carried out in Michigan, compared extensive vegetated, unvegetated, and gravel ballast roofs, with data collected over 430 days. Vegetated roofs held the greatest amount of precipitation. Gravel ballast performed the most poorly. Vegetated roofs retained $60.6 \%$ of rainfall, while unvegetated roofs retained $50.4 \%$. These results indicate that the growth media is the prime determinant of water retention, and that the effect of vegetation on the system is relatively small. The authors 
also found that lower slopes resulted in smaller quantities of runoff, in line with the findings of Berndtsson et al. (2010).

Mentens, Raes, \& Hermy (2006) collected data from 125 different green roofs to assess the performance of intensive and extensive systems, along with gravel-covered roofs. Intensive roofs were found to retain an average of $75 \%$ of runoff over an annual timeframe. Intensive systems retained an average of $50 \%$. Gravel-covered roofs performed the most poorly, at an average of $25 \%$ retention. The difference in performance between intensive and extensive green roofs was attributed primarily to the deeper substrate on the intensive roofs. Neither age of the roof nor slope angle were found to be significantly correlated with runoff. The authors performed a regression analysis on the gathered data to derive an equation that predict runoff of green roofs. The variables in the equation were yearly precipitation and substrate depth. This equation showed an $\mathrm{R}^{2}$ value of 0.78 , indicating that $78 \%$ of the variability in the data could be explained by the included variables.

Berndtsson et al. (2010) also performed a review of existing literature on the topic. Specifically, the authors were interested in investigating the role that green roofs play in affecting water runoff quantity and quality. Through examination of multiple works, it was found that as roof slope increases, the amount of water discharged also increases. The review also found that thicker substrates result in lower amounts of runoff, consistent with other works discussed in this review. Larger precipitation events were found to result in a lower percentage of water remaining on the roof because the roof's maximum holding capacity was reached. Retention percentages ranged widely and depended on location and roof type, but were between 45 and 78 percent. The authors did find that some studies that were reviewed showed contradictory results, particularly in the area of water runoff quality. The authors suggest that this comes from different roof designs and different study conditions.

Gregoire \& Clausen (2011) conducted an experiment in which the water runoff quantity and quality of a modular green roof system was monitored for a period of six months. 
The green roof used a growth medium that was predominantly expanded shale, and was planted with a mix of ten sedum species. The control roof was a protected membrane roof with a 4-ply coal tar membrane, exterior rigid foam insulation and concrete pavers on pedestals. Runoff on the green roof was $51.4 \%$ lower than the control, averaged across the observation period. The majority of pollutants measured were reduced in the runoff of the green roof, with the most significant reductions seen in lead, zinc, and ammonia.

Media type is the second key factor that determines water retention. Generally, green roof substrates are very porous, as this allows them to be light and to drain water quickly. Light, free draining substrates permit installation of green roofs on a larger number of buildings because the overall loads that the roof will undergo are reduced. It is difficult to produce quantitative numbers for comparison of various substrates, as the existing literature consists mainly of studies using only one substrate, or substrates with similar characteristics. Substrates with varying levels of organic content, for example, can affect water retention, as demonstrated by Getter et al. (2007). This organic content can come either from the initial mix of the substrate, or can accumulate over time from decomposing plant matter and being blown in by wind (Berndtsson, 2010).

One of the few studies comparing different substrates was performed by Razzaghmanesh \& Beecham (2014), in Adelaide, Australia. Their study compared intensive and extensive roofs with two different substrates that possessed different hydraulic conductivities $(0.118 \mathrm{~cm} / \mathrm{s}$ and $0.124 \mathrm{~cm} / \mathrm{s})$. With data collected over the course of two years, no statistically significant differences were found among any of the combinations of typology and substrate. However, the climate of Adelaide is significantly drier than Toronto's and as such their results will likely vary from those that would be experienced in Toronto; it is well understood that as precipitation increases, retention decreases as green roofs reach saturation. Due to the low amount of precipitation, mean retention for all combinations was almost always over $90 \%$, a severe deviation from studies performed in climates that experience more humidity and greater quantities of precipitation. 
Simmons, Gardiner, Windhager, \& Tinsley (2008) tested six extensive green roof systems and also compared them to white and black membrane roofs, measuring the quantity of runoff experienced during real world rain events. A major variation among the green roof systems was the use of different a substrate on each. The authors did not have information on the exact makeup of each substrate, as it was proprietary information that the manufacturers would not share. The results displayed highly varied storm water runoff rates among the green roofs for all rain events over $10 \mathrm{~mm}$. Events under this threshhold showed similar results among all green roof systems tested, with no runoff observed. The authors state that a significant contributor to these results are the type of substrate used, but the exact size of the effect could not be extracted from their results due to lack of information about each substrate.

Griffin (2014) investigated whether there was a significant difference in hydraulic conductivity among green roof substrates. Three substrates were tested, with organic contents of $10 \%, 20 \%$, and $40 \%$ by volumetric proportion, and no statistically significant differences were found. These results indicate that while substrate makeup may have some effect on runoff, the effect is smaller than other factors, which is in line with the findings of Razzaghmanesh \& Beecham (2014).

The trend among these studies is showcased in Table 2, which displays the results of each study as well as an average for extensive and intensive typologies, along with results from non-vegetated roofs. Although variations in roof design, project location, vegetation type, and a host of other factors make direct comparison impossible, the averages demonstrate that both green roof typologies offer significantly improved performance over traditional roofs, with the intensive typology displaying the best performance. 
Table 2, Summary of Storm Water Runoff Benefits Reported

\begin{tabular}{|c|c|c|c|c|c|}
\hline Reference & $\begin{array}{l}\text { Extensive } \\
\text { Roof Storm } \\
\text { Water } \\
\text { Retention }\end{array}$ & $\begin{array}{l}\text { Intensive } \\
\text { Roof Storm } \\
\text { Water } \\
\text { Retention }\end{array}$ & $\begin{array}{l}\text { Control Roof } \\
\text { Storm Water } \\
\text { Retention }\end{array}$ & $\begin{array}{l}\text { Length } \\
\text { of Study }\end{array}$ & $\begin{array}{l}\text { Location of } \\
\text { Study }\end{array}$ \\
\hline $\begin{array}{l}\text { VanWoert, Rowe, } \\
\text { Andresen, Rugh, } \\
\text { Fernandez, Xiao } \\
(2005 \mathrm{a})\end{array}$ & $60.6 \%$ & - & $27.2 \%$ & $\begin{array}{c}14 \\
\text { months }\end{array}$ & $\begin{array}{l}\text { Michigan, } \\
\text { USA }\end{array}$ \\
\hline $\begin{array}{l}\text { Mentens, Raes, \& } \\
\text { Hermy (2006) }\end{array}$ & $50 \%$ & $75 \%$ & $19 \%$ & $\begin{array}{l}\text { Review } \\
\text { of other } \\
\text { works }\end{array}$ & $\begin{array}{c}\text { Review of } \\
\text { other works }\end{array}$ \\
\hline $\begin{array}{l}\text { Razzaghmanesh \& } \\
\text { Beecham (2014) }\end{array}$ & $74 \%$ & $88.6 \%$ & - & $\begin{array}{c}24 \\
\text { months }\end{array}$ & $\begin{array}{l}\text { Multiple, } \\
\text { Australia }\end{array}$ \\
\hline $\begin{array}{l}\text { Speak, Rothwell, } \\
\text { Lindey, \& Smith } \\
\text { (2013) }\end{array}$ & - & $65.7 \%$ & $33.6 \%$ & $\begin{array}{c}12 \\
\text { months }\end{array}$ & $\begin{array}{l}\text { London, } \\
\text { UK }\end{array}$ \\
\hline $\begin{array}{l}\text { Getter, Rowe, \& } \\
\text { Andresen (2007) }\end{array}$ & $80.2 \%$ & - & - & $\begin{array}{c}16 \\
\text { months }\end{array}$ & $\begin{array}{l}\text { Michigan, } \\
\text { USA }\end{array}$ \\
\hline Average & $66.2 \%$ & $76.4 \%$ & $26.6 \%$ & - & - \\
\hline
\end{tabular}

\subsubsection{Water Runoff Quality}

There are two major components of water runoff quality, as it relates to green roofs. The first is the growth media itself. The second is the use of fertilizer, specifically the type that is used.

Growth media has a significant impact on water runoff quality, as discussed by Whittinghill \& Rowe (2012). Traditional growth media is generally not used on green roofs because it is heavier than engineered green roof specific growth media. Lighter weight growth media is very coarse, with high porosity. This generally leads to poor quality runoff early in the roof's life, particularly when liquid fertilizers are applied. Traditional growth media, as is sometimes used on agricultural roofs, shows a different trend, with positive effects on water runoff quality, after an initial period of nutrient 
leaching (Rowe, 2011). Once the amount of organic matter in the substrate reaches equilibrium, runoff quality improves. This improvement in runoff quality results from the uptake of pollutants by the vegetation (US EPA, 2009). It stands to reason, then, that as coverage increases, so too will runoff quality. Systems with greater leaf area indices, due to their larger quantity of biomass, should be able to remove more pollutants from effluent.

These findings are supported by Berndtsson, Bengtsson, \& Jinno (2009), who measured the effects on water quality from an intensive and an extensive roof. The extensive roof consisted of sedum with $30 \mathrm{~mm}$ (1.2 in) of substrate. The intensive roof was planted with a variety of bushes and trees, and had a substrate depth of $400 \mathrm{~mm}$ (15.75 in). The studied intensive roof was found to produce higher quality effluent than the extensive roof, with outgoing elements of fertilizer greatly reduced on the intensive roof. Rainwater, particularly in cities, can be polluted, as well as being acidic (Berndtsson, 2010). The findings of Berndtsson et al. (2009) showed neutralization of acid, with $\mathrm{pH}$ increasing from 5 in incoming rain to 7.5 in outgoing effluent. Heavy metals were not found to be significantly impacted by either roof. The authors state that the higher water quality in effluent of the intensive roof is the result of larger plants that can take up greater quantities of nutrients than the extensive roof.

Earlier work by Kohler, Schmidt, Grimme, Laar, Paiva, \& Tavares (2002) came to a different conclusion on heavy metals, finding that quantities of copper, zinc, cadmium, and lead in effluent were significantly reduced. The authors state that this effect will be dependent on the depth of growth media, but no specific data is given. It is difficult to compare these results to the work of Berndtsson et al. (2009), as information on the construction of the roof is not provided.

Berndtsson, Emilsson, \& Bengtsson (2006) studied vegetated roofs on multiple buildings in southern Sweden to evaluate the quality of effluent. Findings were largely similar to other studies discussed here, with heavy metal quantity being generally unaffected, and some release of fertilizer constituents. An important finding was that there was a 
significant 'first flush' effect, where significantly higher concentrations of nitrogen, phosphorus, and some metals are observed early during rain events, and decrease as the rain continues. During dry periods, dry deposition, accumulation of particles from the air, and the presence of gases and aerosols contribute to the build up of pollutants in the roof, which are washed away during the early part of a rain event.

An ongoing concern on runoff quality is the use of fertilizers. For vegetation to be maintained over an extended period it must be supplied with nutrients. Even lowmaintenance species of sedum require an application of fertilizer every 3-4 years (Berndtsson, Emilsson, \& Bengtsson, 2006). Work from many sources acknowledges and establishes that fertilizer use, both in type and frequency, have significant effects on outgoing water quality (Berndtsson, Emilsson, \& Bengtsson, 2006, Emilsson, Berndtsson, Mattsson, \& Rolf, 2007, Whittinghill \& Rowe, 2012). Classically, fertilizers are highly soluble, meaning that they can easily be carried off a roof by water during a rain event. This has negative impacts on outgoing water quality. Generally, these fertilizers have given way to controlled-release fertilizers, which have lower solubility, and thus stay on the roof longer. Controlled-release fertilizers release a small amount of nutrients continually, and over a longer period of time, meaning that less frequent fertilizations are required, and less is lost to runoff.

The major components of fertilizer are nitrogen, phosphorus, and potassium. If high quantities of these elements are present in runoff, they can create water quality problems in receiving water bodies, where they lead to eutrophication, or put additional load on treatment plants. Depending on design, green roofs can serve as sources or sinks of nitrogen. Extensive roofs show the poorer performance among the typologies, although the precise performance will vary from roof to roof. For example, an extensive roof monitored by Moran, Hunt, \& Smith (2005) showed statistically significantly more nitrogen in runoff than in incoming rainwater and in runoff from the control roof. Conversely, Berndtsson, Bengtson, \& Jinno (2009) showed slightly reduced nitrogen runoff on the extensive roof in their study. The intensive roof in the same study showed significantly lower nitrogen runoff. This study showed the same trend for phosphorus, 
with the extensive roof adding phosphorus to runoff, even though the last fertilization had taken place two years prior. The intensive roof showed no phosphorus release, though it has not been fertilized in the preceding years. The third major element, potassium, was found in high concentrations in the runoff of both extensive and intensive roofs, with average quantities seven times higher than was present in incoming rainwater. These results indicate that green roofs are, on the whole, not effective at treating incoming water, and can actually contribute to its pollution, depending on the fertilization scheme employed on the roof.

Emilsson et al. (2007) found that application of soluble fertilizer led to high levels of nutrient concentration in effluent at all quantities of application. Test plots that were treated with a moderate level of controlled-release fertilizer $\left(5 \mathrm{~g} \mathrm{~N} / \mathrm{m}^{2}\right)$ showed only $25 \%$ of the total nitrogen runoff as those plots treated with controlled release fertilizer and the same amount of conventional soluble fertilizer.

Conclusions can be drawn from these studies in two categories. First, green roofs are effective at removing some contaminants (fertilizer constituent components, neutralization of acid), and ineffective at removing others (heavy metals). Second, the highly porous nature of most green roof substrate leads to very poor effluent quality when liquid fertilizer is applied. Controlled-release fertilizer provides a steady flow of nutrients over a longer timeframe, impacting effluent quality to a smaller degree, and thus is highly preferable from a runoff water quality perspective.

\subsubsection{Maintenance}

Extensive green roofs are generally designed to be self-sufficient, requiring little input once they have been constructed and established, in terms of both labour and water (VanWoert et al. 2005a). These systems are therefore simpler, and easier to justify from a cost perspective, as there are few ongoing costs associated with such systems, assuming proper design and construction at the outset. Intensive green roofs have different maintenance requirements, needing regular care (Molineux, Fentiman, Gange, 2009). 
This increases the ongoing costs associated with these projects, as maintenance staff is required, and water supply is also generally necessary (Bianchini \& Hewage, 2012).

An investigation by Wong, Wong, Tay, Ong, \& Sia (2003) evaluated maintenance costs for green roofs based on consultation with firms actively engaged in the green roof industry. Findings indicated that the ongoing maintenance costs of an extensive green roof were the same as for a conventional inverted built-up roof. This scenario assumed twice-monthly watering and weeding, with replanting of any dead plants. Inspection to ensure proper drainage was assumed as being carried out twice a year. An intensive case was also evaluated, assuming maintenance on alternating days and a replanting when the roof reached 15 years in age. This scenario resulted in a higher overall maintenance cost, coming in at 1.5 times higher than for a conventional built-up roof when planted predominantly with shrubs and 2 times higher when planted predominantly with trees.

A cost-benefit analysis carried out by Bianchini \& Hewage (2012) came to a different conclusion. Using an earlier work as a basis, operation and maintenance costs of intensive and extensive green roofs were assumed to be similar. Values for extensive roofs were assumed to be between $\$ 0.65 / \mathrm{m}^{2}$ and $\$ 13.46 / \mathrm{m}^{2}$, while intensive roofs were between $\$ 0.70 / \mathrm{m}^{2}$ and $\$ 13.50 / \mathrm{m}^{2}$, a difference of less than $10 \%$ for the low estimate and less than $0.5 \%$ for the high estimate between the typologies. Both typologies were assumed to follow a standard distribution. Under each evaluated case, the net present value of the green roof was positive, indicating that even under scenarios where maintenance costs are assumed to be high, installation of a green roof was still a profitable investment.

Proksch (2011) investigated five rooftop farms throughout North America across a variety of parameters, one of which was the number of employees. All of the farms had less than five employees, with most having one full or part time staff member, supported by many volunteers. Exact volunteer numbers were not given, but it is made clear that a significant portion of the labour is being performed by volunteers. As such, while the total labor may be significantly higher on rooftop farms than the other typologies, the 
total operating costs may be somewhat comparable, as a small number of people are actually being paid.

Ryerson University's Rye's HomeGrown program is a rooftop agriculture project consisting of $930 \mathrm{~m}^{2}\left(10,000 \mathrm{ft}^{2}\right)$ of farmed area in Toronto's downtown core. The farm is run by one part-time staff who works 20 hours per week, and supplemented by 40 hours of volunteer labour per week (Arlene Throness, personal communication, July 17, 2015). The total of 60 person-hours per week makes up the routine work that is required to run the farm, including planting, harvesting, weeding, and general roof maintenance tasks. Because much of the work is performed by volunteers, efficiency is low, due to the high turnover and consequent retraining of volunteers. As established by Proksch (2011), this is likely a common issue with agricultural roofs, as volunteers are widely used across that typology.

Green roofs vary greatly in their design, and their maintenance requirements range widely as well. Extensive systems, designed with a low maintenance footprint in mind, can require no more maintenance in terms of dollars than a conventional roof, while rooftop farms often require full time staff, with significant volunteer support. The maintenance profile is largely dependent on typology, and requires careful consideration by designers.

\subsubsection{Amenity}

Beyond environmental performance benefits, green roofs provide urban green space, which is at a premium in increasingly built-up urban environments. It is widely accepted that access to nature and green space provides benefits to people in the city, offering space for relaxation, and escape from the sounds and stresses of the city (Chiesura, 2004). As urban intensification continues, consumer tastes are also changing, with demand for greater access to these spaces is rising (Dobrian, 2014).

The term amenity is used here to encapsulate people's enjoyment or preference for something, beyond its utility. Concepts such as "offering space for relaxation," for 
example, are difficult to put a discrete value on. To be useful, however, these concepts must be made measurable, requiring translation of a user's like or dislike some quantifiable figure. Generally this is done by converting amenity into a dollar figure, measuring people's willingness to pay for something. Because green roofs are not a standalone product, but are instead part of the larger system of a building as a whole, determining their value typically involves the use of a hedonic model, in which the item being investigated is broken down into parts, so that the impact or value of each piece can be determined (Rosen, 1974).

Ichihara \& Cohen (2010) used the hedonic method to determine the value of green roofs in New York City. Using a sample of 44 apartment units in the Battery Park City neighbourhood, the authors performed a regression analysis to tease apart the relationships between green roofs, proximity to subway, proximity to parks, etc. Buildings with green roofs were found to have $16.2 \%$ higher rents than those without. The buildings in this study each had a different type of green roof, with one intensive, one extensive, and one mixed system. The authors did not take green roof type into account, but instead used a yes/no variable stating whether a green roof was present or not. This means it is not possible to know whether one typology was preferred over another, only that as a whole, buildings with green roofs increased rents by $16.2 \%$.

Knut et al., (2012) also utilized the hedonic method to quantify the amenity of green roofs in terms of economic valuation. The authors sought out existing published data on the value of green roofs and averaged the findings of this data to determine a value per square metre per household per year. The result is an estimate of approximately $\$ 16-25$ CAD (given in the article as EUR 12.30-18.70) per square meter greenery per household per year. The authors acknowledge that these values do not take into account any measures of quality of construction, which would impact the overall values obtained.

Peck et al. (1999) state that good tree cover yields an increase in house value of 6-15\%, and that green roofs offer similar visual and environmental amenity. Thus, the authors argue, the value of green roofs can be assumed to be similar. This approach is similar to 
that seen in other works (Knut et al. 2012, Tomalty \& Komorowski, 2010), as there is relatively little data available on the value of green roofs. As such, approximations are made in many of the published works on the subject.

Tomalty \& Komorowski (2010) investigated the relationship between green roofs and property values, examining both recreational extensive systems, and urban agriculture projects, which they term "productive gardens." Their work required similar assumptions to Peck et al. (2010); the authors assumed that an extensive green roof confers the same benefit as if the building was abutting a grade-level park. The increase in value for this system is found to be $20 \%$. For agricultural green roofs, the value is assumed to be the same as if the building abutted a grade-level community garden. The increase in value for the agricultural roof is found to be $7 \%$. The authors also found benefits to surrounding properties based on the percentage of the building that has a view onto the rooftop green space. Values for surrounding buildings range from $2-7 \%$, depending on the view that the surrounding buildings have of the one with the installed green roof. For each scenario, a formula is provided to estimate the benefit derived from the addition of a green roof.

Besides hedonic and assumptive methods, qualitative methods can be used to identify a person's preference for various types of green roofs. As discussed earlier, these are harder to quantify, but can nonetheless indicate trends. Lee, Williams, Sargent, Farrell, \& Williams (2014) interviewed office workers, showing them pictures of various roofs, including bare concrete, intensive, and extensive green roofs. All green roofs were preferred over bare concrete. Vegetated roofs with taller, green vegetation were preferred over low-growing succulents. Study participants also preferred roofs that were moderately varied in their vegetation, as opposed to roofs with a single height and color. Respondents saw taller green vegetation as implying that greater care was being taken of the roof, which improved their perceptions of it. This study did not directly address urban agriculture, but participants' preference for varied, green vegetation over roofs with a single height indicates that perhaps such roofs would be well liked. 
Rooftop agriculture generally takes place on intensive systems, due to their deeper substrates and tolerance for the higher weights that come with the need for more frequent irrigation. However, recent work by Whittinghill, Rowe, \& Cregg (2013) shows that it is possible to produce herbs and vegetables on roofs with depths as shallow as $10.5 \mathrm{~cm}$. In their study, the authors planted tomatoes, green beans, basil, and chives both on a green roof and in the ground to compare yields. Overall yields were similar between both locations. In some cases, the green roof resulted in statistically significantly higher yields, as fewer pests were present on the roof. There were no species that performed significantly poorer on the roof than in the ground. These results are particularly valuable because this study was undertaken in East Lansing, Michigan, which shares the same climate zone as Toronto. No such roofs were found outside of this study, but indicate a possible future direction of rooftop agriculture.

Agricultural roofs also offer the additional benefit of food production. Through producing food locally, the distance it travels before consumption is reduced, and also allows it to arrive fresher. The total benefits of local food production are hard to quantify, as many factors are involved, but it is widely understood to be a positive. Productivity of rooftop farms varies, with reported yields ranging from $0.84 \mathrm{~kg} / \mathrm{m}^{2}$ to $2.53 \mathrm{~kg} / \mathrm{m}^{2}$ (Arlene Throness, personal communication, July 17, 2015, Proksch, 2011). These yields are significantly lower than those obtained on ground level farms in Ontario, which average $10.9 \mathrm{~kg} / \mathrm{m}^{2}$ for vegetables (Statistics Canada, 2015), due to the smaller scale and inability to use heavy machinery on rooftops.

The reviewed works agree that green roofs are desirable from an amenity perspective. It is clear that green roofs are preferred over traditional roofs in both monetary and qualitative terms, although this varies among the typologies; intensive and extensive roofs are valued the more highly than agricultural roofs. However, agricultural roofs offer the additional benefit of providing local food production. Though yields are lower on roofs than ground level farms, they are occupying space that was previously unused, and reduce the distance food travels prior to consumption. 


\subsubsection{Irrigation}

Irrigation requirements are closely linked to storm water management. Since green roofs are implemented to reduce or slow the runoff of storm water from roofs, it is imperative that their efficacy in this regard is not compromised. Crops are understood to have relatively high water needs, especially when compared to common green roof plants such as sedum (Brouwer \& Heibloem, 1986). As a result, an irrigation system is required for urban agriculture roofs, and is often also employed on intensive and extensive roofs as well.

On ground-level farms, drip irrigation is understood to be the most efficient method of supplying water to plants, as it limits the amount of water lost to evaporation or blown away from beds during application (Fortier, 2014, Gleik, 2002). The use of porous substrates on green roofs, however, can alter this dynamic. Because green roof substrates are very coarse, capillarity is greatly reduced; water moves vertically faster than in regular soil, and does not move horizontally much, if at all. This results in overhead irrigation performing better than drip irrigation or subsurface irrigation in these scenarios, with less wasted water (Rowe, Kolp, Greer, \& Getter, 2014). However, this is not necessarily the case for agricultural green roofs, which sometimes make use of less porous substrates (Proksh, 2011). In these cases water is retained longer and allows greater horizontal movement within the substrate, rather than allowing the water to drain down and make its way off of the roof.

Rowe et al. (2014) carried out an experiment with three different green roof substrates. Each of the substrates had a high infiltration rate, well above those seen in pure sand, the most coarse soil classification established by the United States Department of Agriculture (Gulliver, Erickson, \& Weiss, 2010). In the experiment, three types of irrigation were tested: overhead, surface drip, and sub-surface drip. Overhead irrigation showed the best plant health and substrate wetting, as water was applied relatively evenly across the test bed. Surface and sub-surface drip irrigation showed poorer performance, with sub-surface performing particularly poorly. These results are attributed to the inability of the substrates to allow water to move horizontally - water introduced at the subsurface level 
simply moved downward through gravity, causing significant waste. Overall wastewater percentages were $33.5,79.2$, and $86.8 \%$ for overhead, drip, and sub-surface irrigation methods, respectively. The authors also measured volumetric moisture content at three points in time: initial conditions, after 15 minutes of watering, and at 40 minutes, which was 10 minutes after terminating the watering. Initially, all test plots had similar moisture levels. At the 15 minute interval, The surface drip irrigation method showed higher moisture levels, while overhead and sub-surface irrigation showed roughly similar levels. At 40 minutes, however, both drip irrigation methods had shed a large percentage of their moisture, while overhead showed higher values at this point than at 15 minutes due to the continued accumulation of water between 15 and 30 minutes. On average, drip irrigation showed $63 \%$ of the water volume of overhead irrigation. Additionally, the overhead system applied less than half of the water used by the two drip irrigation systems. This demonstrates clearly that overhead irrigation was able to provide better coverage, with less waste, with less water used. Thus, overhead irrigation is preferable on most green roofs, since lightweight media is so widely used.

No sources were found that investigated the performance of standard soil on green roofs. As a result, other, similar sources needed to be located that could serve as stand-ins. The difficulty was that studies of on-ground irrigation do not attempt to quantify runoff, as the on-ground fields in these studies are part of the larger landscape and not compartmentalized as those on green roofs are. This makes measurement of runoff quantity difficult. Instead, these studies tend to focus on overall irrigation water use efficiency, a measure of how much water applied to an area is lost during application, conveyance, storage, and other related factors (Hamdy, 2007). When investigating overall water use, measurements are instead given as a percentage reduction. This is the inverse of wastewater measurements as seen in the work of Rowe et al. (2014), whose measurements were taken at the outlet of the roof. The studies discussed below evaluate efficiency based on reduction in use, which is measured at the inlet, or point of origin of the water. 
Hanson, Schwankl, Schulbach, \& Pettygrove (1997) investigated performance differences among standard and drip irrigation schemes in fields of lettuce. Using drip irrigation, an average of 59\% less water was applied to the field compared to standard irrigation practices. Measurements were carried out over three growing seasons, with 43, 74 , and $61 \%$ less water used in the first, second, and third seasons, respectively. During each growing season no change in yield was observed compared to the standard irrigation method. This is important to note, as a reduction in water use that resulted in a reduction in yield would be seen as counterproductive, particularly on an agricultural roof where a driving goal is the production of food.

Ibragimov, Evett, Esanbekov, Kamilov, Mirzaev, \& Lamers (2007) also investigated a comparison between standard and drip irrigation. Focusing on cotton production, their work measured yields and water use over three growing seasons. Drip irrigation showed an average of $32 \%$ reduction in water use over the standard irrigation method. These findings are in line with those found by Hanson et al. (1997). Although the exact percentages differ, the trends hold the same, and variation between the two can be explained by the differences in crop type, location, and precipitation quantities.

Substrate depth also plays a role in the required irrigation on a roof. An investigation by Guo, Shang, \& Liu (2014) found that there was a significant decrease in irrigation time fraction as substrate depth increased. This held true in both semi-arid and humid climates, though the trend was stronger in the humid climate. Irrigation time fraction reduction was greatest as substrate depth increased from $100 \mathrm{~mm}$ to $200 \mathrm{~mm}$, after which returns began to drop significantly. Addition of a water retention layer significantly reduced the irrigation time fraction. These results display that green roofs featuring deeper substrates and water retention layers provide significantly more storm water runoff reduction than those with thinner substrates as a result of requiring less irrigation. Similar findings have been observed by Arlene Throness, coordinator of Rye's HomeGrown, a rooftop agriculture project at Ryerson University, who has found that the roof's 250-300 mm (1012 inch) soil depth retains moisture for up to a week between waterings (personal communication, July 17, 2015). 
The reviewed works demonstrate that rooftop irrigation differs significantly from that at ground level. The high porosity of green roof substrate results in drip irrigation being highly inefficient, with wastewater percentages above $80 \%$. Above ground irrigation systems perform much better, with significantly less wastewater. Although it is not common, where traditional soil substrates are used, drip irrigation can be effective due to a greater capacity for lateral movement of water.

\subsubsection{Conclusion}

Through investigation of published works investigating each criterion, the design options behind those variations were identified. Each criterion selected for use in the evaluation tool was chosen because of its varying performance among each green roof typology, which was borne out by the literature review. Section 4.4 discusses each of these design options, and their impacts on performance in depth. 


\section{Evaluation Tool}

\subsection{Introduction}

The major output of this project is the development of decision-making evaluation tool that helps users understand the impact of making specific choices in the design of a green roof, and offer data to help decide among the possible options. Broadly speaking, green roofs are widely understood at a conceptual level in terms of the benefits that they can provide. This evaluation tool is an effort to attempt to bring together some of the disparate works that have been carried out by researchers striving to increase knowledge of this relatively young field. In the case of some criteria, there is a scarcity of data that makes drawing concrete conclusions difficult. As the body of knowledge surrounding green roofs continues to grow, this situation will no doubt change. This evaluation tool has been designed to allow for the incorporation of new information as it becomes available. As such, this work presents a view of green roofs as they are currently understood, and gives power to the user to apply that understanding in the way that is the the most relevant to them, and based on the requirements of their project.

The goals of the evaluation tool are that it should be easy to use, and aid in decisionmaking. To do this it needs to be backed up by high quality data and be easily understandable by people with little in-depth knowledge of green roofs. As a result, the aim of this evaluation tool is to create a system that is flexible in allowing the user to input the characteristics of a planned roof and view the results. The results are shown in two ways: a description of the impact of each choice on performance, and as a points total, which gives an overall evaluation of the proposed system at the end of the process.

This also allows users to account for characteristics or choices that may not have been expressly included in the evaluation tool. An effort has been made to include a wide variety of typologies and options, but it is inevitable that users will experience scenarios that fall outside of those that have been included. By providing information about the impact of a choice, the user can, using this information, assess which included option is the closest analogue to their case. For example, if a user is using a substrate that offers storm water retention falling outside of the trend discussed in Section 5.3.1, they can 
instead look directly at the performance metric of retention rather than the proxy of depth that is given there as a guideline.

Overall results are also determined by the user, who is given the freedom to define success in their own terms; the relative importance of each category is set by the user, depending on the goals of their project. If, for example, a project is particularly focused on providing high storm water retention, the user can increase the weight in that category, while downplaying another. This flexibility increases the usefulness of the evaluation tool by acknowledging that not all projects come from the same perspective or are looking to meet the same goals. This is discussed in greater depth in Section 5.2.

\subsubsection{Terminology}

Throughout the rest of this document, the term "criteria" is used to refer to each of the five criteria established in Section 3. The term "variable" is used to refer to each set of design options used to generate a score for each criteria. These criteria are established and discussed in Section 4.4.

\subsection{Precedents}

In the early stage of developing the evaluation tool, similar existing works were sought. Only one was found, a work developed by Roehr \& Primeau (2010), who developed a decision-support evaluation tool. Their tool is targeted at both policy-makers and green roof designers and is applicable at individual building, neighbourhood-, and city-scales. It utilizes a point score system with points assigned to a number of categories. These categories were established and weighted based on the authors' judgement. Irrigation was held as the most important, making up 12 of the total 20 points. Climate zone, building structural strength, and availability of alternative storm water management methods make up the other 8 points, divided approximately evenly. In this tool, a proposed green roof project that is able to achieve 10 points is deemed to 'pass,' and is a good candidate for being implemented. Because of the emphasis on irrigation in this system, a roof that utilizes potable water for irrigation, with electricity provided from the municipal grid, the project achieves 0 of the 12 possible points in this category, making it impossible to 
achieve the requisite 10 points. If the project implements alternative energy, such as wind or solar power, it achieves 2 points, meaning that it is possible to meet the 10 point threshold if maximum points are achieved in the three other categories.

A shortcoming of this work is the lack of consideration of the type of irrigation system that is present. As discussed in Section 3.2.5, in typical on-ground applications above ground sprinkler-type irrigation systems have an efficiency of around $50 \%$, meaning that about half of the water applied to the field is actually taken up by the plants. Drip irrigation systems, in which tubes are laid on or buried inside the growth media can achieve efficiencies of $90 \%$ or higher (Faulkner, 2014). These values differ on green roofs, which typically use fairly porous substrates (Rowe et al. 2014), though this is not necessarily the case for urban agriculture roofs. The authors mention that drip irrigation should be considered during design, but no points are awarded for this. A reduction in usage of $50 \%$ should surely be counted as a positive, but no credit is given for this.

As mentioned above, this tool hinges on the subjective decisions made by the authors as to the relative importance of each category. The authors themselves acknowledge that points are awarded based on their judgement. This was done because the authors feel that water management is the most important factor in the implementation of green roofs - a view shared by many.

The authors also consider the context of the project - if a site is surrounded by pervious surfaces, a green roof is less important, as rooftop water could simply be moved off the roof and discharged through these surfaces. Alternatively, if a building is a highly builtup downtown area surrounded by pavement and concrete, the implementation of a green roof becomes more relevant, as there are fewer opportunities for other water management methods. Because of the aim of this tool, context is important.

There are significant differences between Roehr \& Primeau's (2010) work and the evaluation tool presented in this paper. For example, the inclusion of context is not considered in this evaluation tool, as the evaluation tool presented here is not attempting 
to help users make a choice of whether or not to implement a green roof, but rather to help them make a decision about which typology to use once it has been decided that a green roof will be built.

\subsection{Weighting \& Scoring}

In developing this evaluation tool, an early consideration was that the tool be able to accommodate a wide set of users. With this in mind, it was necessary to consider that a varied user group will no doubt have different priorities, and have different motivations for considering a green roof for their project. To this end, it was important that the evaluation tool not be prescriptive in telling the user what the author feels is most important. Instead, a weighting system has been created that allows users to input their own consideration of the relative importance of each category for their specific project.

The first step taken was to establish an even number of points across each category. This removes any intrinsic valuation of one section over another in the evaluation tool and provides a common unit of measurement; since each variable is given the same number of points, comparison across variables is quick and easy to understand. To this end, each variable was assigned a total of 5 points, with 5 being the highest possible score, and 0 being the lowest.

The structure of the evaluation tool requires weighting at two stages in some cases. For criteria containing only one variable (Water Runoff Quantity, Maintenance, and Irrigation), only the criteria level weighting was required. However, the criteria of Water Runoff Quality and Amenity contain more than one variable, and thus require more granular control. These criteria are built into the evaluation tool with an additional level of weighting that is applied only within that criterion. The score for each variable is multiplied by the weighting, as a percentage, and the total of each variable is then taken to obtain an overall point total for that criteria. This allows the user to distinguish not only between each criterion, but also among variables within each criterion. 
To obtain a total score, the points obtained in each category are multiplied by the weighting assigned, and the project obtains an overall score that accounts for the user's preference. This work is handled by the tool, which performs all calculations that are required. This total score demonstrates how successful the project will be in meeting the user's goals as established through the weighting system, in concert with the selected characteristics of the roof in question.

\subsection{Development}

\subsubsection{Storm Water Runoff Quantity}

In attempting to judge the performance of green roofs in the aspect of runoff quantity, it was important to establish a metric of performance, and then determine the factors that influence performance in this area. As discussed in Section 4.2.1, the chief factors here are the depth of the growth media, and the type of growth media. Both of these factors are the key components that contribute to the issue at the heart of runoff quantity: storm water retention. To address aging and overstressed storm water management infrastructure, green roofs need to offer retention of storm water, since this reduces the total volume of water that must be handled by the infrastructure. While it is understood that both depth of growth media and type of growth media affect overall retention, depth has been selected for use in this evaluation tool. Based on the current body of published research focusing on the impacts of substrate type it was not possible to draw quantifiable conclusions. This is not to say that media type does not impact storm water retention Getter \& Rowe (2006) and Simmons et al. (2008) both demonstrate and discuss that media type can impact retention - but there is a scarcity of data at present. As more research is carried out, it will become possible to quantify these effects more concretely. Vegetation was also considered in terms of its impact on runoff quantity, but as discussed by VanWoert et al. (2005a), indications are that vegetation has a negligible impact, so this variable was omitted from the evaluation tool.

This relationship is also affected by the amount of precipitation that a location experiences. However, this evaluation tool is developed for use at the individual building 
scale with the aim of allowing users to compare amongst multiple options for the same building. As a result, precipitation is assumed to be a constant, as location is assumed to be constant. In addition, the scope of this evaluation tool has been developed specifically with the climatic conditions of Toronto, Canada in mind, which will be treated here as having a single climate. Thus, rainfall is not included in the evaluation tool.

The depth of growth media is identified by the majority of studies as a chief determinant of runoff performance. Work by Mentens et al. (2006) brought together data from 125 green roof experiments where runoff quantity was measured and used this data in a regression analysis to develop an equation for determining the annual runoff for green roofs. The regression performed by the authors yielded an $\mathrm{R}^{2}$ of 0.78 , indicating that the equation can explain almost $80 \%$ of the variability in the data. The authors did not account for the type of growth media in their investigation, and this is likely one of the major factors that negatively impacted their $\mathrm{R}^{2}$. The derived equation is given below:

$$
\mathrm{RO}=693-1.15 \mathrm{P}+0.001 \mathrm{P}^{2}-0.8^{*} \mathrm{~S}
$$

Where,

$\mathrm{RO}=$ annual surface runoff, $\mathrm{mm}$

$\mathrm{P}=$ yearly precipitation, $\mathrm{mm}$

$\mathrm{S}=$ substrate depth, $\mathrm{mm}$

The authors also developed an equation for determining runoff on non-greened roofs, which is shown below:

$$
\mathrm{RO}=0.81 * \mathrm{P}
$$

This second equation, while not explaining a green roof scenario, offers insight into the returns associated with increased substrate depths on green roofs. The green roof equation gives almost perfectly linear results, meaning that a constant increase in substrate thickness yields the same reduction in runoff quantity, no matter the depth. The 
non green roof, though, shows significantly worse performance even when compared to a green roof with even $25 \mathrm{~mm}$ of substrate. This is shown in Table 3 below. For these calculations, a yearly precipitation value of $831.1 \mathrm{~mm}$ was used, based on Environment Canada (2015) weather normals for Toronto.

Table 3, Relationship Between Substrate Depth and Runoff to be Used in the Evaluation Tool

\begin{tabular}{|c|c|c|}
\hline Substrate Depth, mm & Runoff, mm & Runoff Reduction, \% \\
\hline 0 & 673 & 51 \\
\hline 25 & 408 & 58 \\
\hline 100 & 348 & 63 \\
\hline 150 & 308 & 70 \\
\hline 225 & 248 & 77 \\
\hline 300 & 188 & 100 \\
\hline 550 & 0 & \\
\hline
\end{tabular}

These results fall in line with values obtained from green roof experiments. Getter \& Rowe (2006) surveyed results from five experiments, and found that they were capable of reducing storm water runoff by $60-100 \%$. Through examination of the results obtained through the formula developed by Metents et al. (2006), it can be understood that even a very thin substrate layer offers significant performance improvements over a case without a green roof. This is to say that while a green roof with a very thin layer of substrate does not perform as well as one with a much thicker layer, it is still highly preferable over no substrate at all. 
To determine the boundaries for the brackets in this section, the existing Toronto Green Roof Construction Standard (2013) was examined, which states that,

"When structurally possible, the growing media shall be at a minimum $100 \mathrm{~mm}$;

or

The applicant shall provide a report confirming that the engineered system as designed provides plant survivability comparable to that of an un-irrigated system with growing media at minimum $100 \mathrm{~mm}$."

As such, a depth of $100 \mathrm{~mm}$ is used as the boundary for the lowest bracket in the category. The second bracket is established with an upper boundary at $150 \mathrm{~mm}$, based on the commonly accepted boundary between extensive and intensive systems (Berndtsson, 2010, Mentens, Raes, \& Hermy, 2006). Two brackets are established for intensive systems, with the lower bracket capturing roofs with between 150-300 mm of substrate. The upper bracket contains roofs with $300-535 \mathrm{~mm}$ of substrate. This depth of media is capable of capturing $75+\%$ of runoff. Following the equation of Mentens et al. (2006), retention reaches $100 \%$ at a depth of $535 \mathrm{~mm}$. Roofs with this depth of media are not common, but can be seen on some agricultural roofs (Proksch, 2011).

Table 4, Evaluation Tool Point Allocation for Different Substrate Depths

\begin{tabular}{|l|c|c|c|c|c|}
\hline Substrate Depth (mm) & $<100$ & $101-150$ & $151-300$ & $301-534$ & $>535$ \\
\hline Storm Water Retention (\%) & $<58$ & $58-63$ & $63-77$ & $77-99$ & 100 \\
\hline Points & 1 & 2 & 3 & 4 & 5 \\
\hline
\end{tabular}

\subsubsection{Storm Water Quality}

In developing variables of assessment for storm water quality, it was first important to determine the contributing factors. Based on the available literature, it was possible to discern two separate aspects of water quality that need to be addressed here: addition of contaminants to outgoing water, and reduction of contaminants from incoming water. 
Addition of contaminants to effluent results largely from fertilizer use (Emilsson, Berndtsson, Mattsson, \& Rolf, 2007). This allows fertilizer use to be used as one aspect of evaluation of water quality. Reduction of contaminants is generally limited to the constituent components of fertilizer as discussed by Berndtsson et al. (2009) and Berndtson et al. (2006). Different roofs are shown to offer varied performance in this area, offering another avenue of evaluation.

As discussed above, green roofs can contribute negatively to outgoing water quality. This trait is linked closely to the application of fertilizer, which is generally required at some interval, beyond the initial establishment phase. This forms the first variable for determination of runoff water quality. The amount of published information in regards to this variable is small, and impacts are hard to quantify. General trends can be easily observed, but there is a great deal of variability among roofs, among fertilizers, and application schedules that specific numbers cannot, at present, be obtained. Future works in this area will allow for a deeper analysis to be undertaken.

The work of Emilsson et al. (2007) investigated the impact that fertilizer type has on runoff quality. Conventional soluble fertilizer was found to create a rapid increase in concentration of nutrients that far exceed the ability of the plants to use it. This led to significantly higher quantities of these elements in runoff. These concentrations declined exponentially, soon leaving the substrate with very low levels of nutrients. On the test plots that received controlled-release fertilizer, nutrient concentrations in runoff were significantly lower, causing far less negative impact to runoff quality. Application of 5 $\mathrm{g} / \mathrm{m}^{2}$ of soluble fertilizer caused an increase in runoff of approximately $300 \%$ for nitrogen, $700 \%$ phosphorus, and $2000 \%$ potassium over plots fertilized with the same amount of controlled release fertilizer. These results indicate the significant performance differences between soluble and controlled release fertilizers and highlight that it is strongly preferable to use controlled release products.

However, it is also possible that a roof might be designed that does not require fertilizer. When supplied with fertilizer, some species experience growth at a rate that leaves them 
vulnerable to drought conditions, as biomass is higher and the plants are less hardy. Some species such as junegrass and showy goldenrod, for example, have been shown to have an inverse relationship between fertilizer use and survival rates (Berndtsson, 2010). A roof that does not require the use of fertilizer has the best potential for not negatively impacting runoff quality, and is positioned as the category that offers the most points here. It is also clear that controlled-release fertilizers are highly recommended for green roofs as they limit the potential for degraded quality of runoff. There are no benefits, from a runoff quality perspective, to using regular soluble fertilizers. As such, controlledrelease fertilizers are given a moderate number of points, and soluble fertilizers are awarded none.

Table 5, Evaluation Tool Point Allocation for Different Substrate Depths

\begin{tabular}{|l|c|c|c|}
\hline $\begin{array}{l}\text { Fertilizer } \\
\text { Type/Use }\end{array}$ & Soluble & Controlled-Release & No Fertilizer \\
\hline Effects & $\begin{array}{c}\text { Significant impact on N-P-K } \\
\text { in effluent }\end{array}$ & $\begin{array}{c}\text { Small impact on N-P-K in } \\
\text { effluent }\end{array}$ & $\begin{array}{c}\text { No adverse } \\
\text { effect }\end{array}$ \\
\hline Points & 0 & 3 & 5 \\
\hline
\end{tabular}

The second variable in assessing runoff quality deals with the removal of contaminants. As discussed by Berndtsson et al. (2009), larger plants provide a greater capacity for the uptake of nitrogen, phosphorus, and potassium, the main building blocks of fertilizer. If left in effluent, these elements can make their way into receiving bodies of water where they cause adverse effects like eutrophication, upsetting these ecosystems (USGS, 2014a, 2014b). To establish a system of comparison, leaf area index is used here to evaluate the difference between one green roof typology and another. Leaf area index is a dimensionless variable that is defined as "the total one-sided area of photosynthetic tissue per unit ground surface area" (Jonckheere, Fleck, Nackaerts, Muys, Coppin, Weiss, \& Baret, 2004). Thus, a planted area with a leaf area index of 5 would mean that for each $1 \mathrm{~m}^{2}$ of ground there are $5 \mathrm{~m}^{2}$ of leaves. It is a method of assessing the amount of 
vegetation in an area, as leaves serve as the main point of interaction between vegetation and the world around them and are thus a key metric in the evaluation or comparison of vegetated spaces. As such, leaf area index is used in this evaluation tool as a proxy for the quantity of vegetation present on a roof.

To establish values for different planting regimes, the leaf area index of each regime needs to be established. This is difficult, as it is cumbersome to calculate leaf area index generally, the process is destructive, with the leaves of a set area being harvested and their area measured (Pocock, Evans, \& Memmott, 2010). Additionally, the vegetation needs to exist for it to be measured, which is not the case for a green roof that has yet to be built. To address this, known existing values are used to establish ranges that encompass each green roof typology.

Blanusa, Monteiro, Fantozzi, Vysini, Li, \& Cameron (2013) found the leaf area index of a mixed sedum mat (sedum album, sedum spurium, sedum acre, sedum sexangulare) to be 2.29. Sedum species grow small and low to the ground, yielding fairly low leaf area indices. This mix is very similar to that of the extensive roof investigated by Berndtsson et al. (2009), which contained 40\% sedum album, 40\% sedum spurium, 5\% sedum sexangulare, and 5\% sedum ewersii as described in an earlier work on the same roof (Emilsson \& Rolf, 2005). The leaf area indices are therefore assumed to be similar.

By way of comparison, Pocock et al. (2010) found that the leaf area index of a grass field averages 4.1 across seasons, while woodland averages 8.0, mature hedgerows average 6.8 , and isolated standing trees average 3.9. Intensive green roofs vary greatly in their design, and these values offer a range that fits many of the likely scenarios that might be experienced.

Values for crops are wide-ranging, as the value will be significantly affected by the type of crop, spacing of rows, and irrigation patterns. Vina, Gitelson, Nguy-Robertson, \& Peng (2011) investigated the leaf area index of two configurations of soybean crops, one that was rainfed, and another with an irrigation system. Soybeans are a moderate size 
plant, generally growing up to $1.0 \mathrm{~m}$ in height (OMAFRA, 2009), making them a good proxy for many of the species grown on rooftop farms. The results of Vina et al. (2011) indicated an average leaf area index of 2.1 for those watered by the rain, and 3.3 for those given supplemental irrigation. These values are averages that include the open space between rows. Due to the harsh conditions on rooftop farms, it is assumed that all crops will be given supplemental irrigation, so the value of 3.3 is used.

This value is in line with results found by the Oak Ridge National Laboratory (2001), which investigated field measurements from nearly 1,000 different sites in different biomes throughout the world. Over 88 observations for the crop biome, average leaf area index was found to be 3.62. Various temperate forest biomes were found to have leaf area indices between 4.63 and 5.7. Forest biomes present in Canada showed an average leaf area index of 5.68 .

Based on the findings of Blanusa et al. (2013) an established sedum roof is assumed to have a leaf area index of 2.3. No vegetation profiles that are likely to exist on a green roof were found to have indices lower than this, so this value is established as the boundary of the lower bracket. Because the measured effects of extensive and intensive roofs by Berndtsson et al. (2009) only addressed roofs that fell into the 'Low' and 'High' categories in Table 6, the effects of the 'Medium' category had to be interpolated. Values from Oak Ridge National Laboratory (2001) and Vina et al. (2011) yield a range for crops from 3.3 to 3.62. The values given by Oak Ridge National Laboratory (2001) have a fairly high standard deviation, indicating that there is significant variance among the crop biome. This is the result of differences in crop spacings, heights, and foliage quantities across the observed sites. As such this bracket's upper boundary is established based on the lowest observed value for tree cover of 4.63. The upper bracket begins here, and contains all planting regimes that show a high leaf area index as indicated by the literature discussed above.

Points are awarded on the basis of relative performance. The 'High' category is awarded the maximum number of points, since this is the highest possible benefit that was 
obtained. The 'Low' category is awarded one point, as it offers some improvement in water quality, but significantly less than the 'High' category. Due to the wide leaf area index band covered by the 'Medium' category, it is awarded a number of points positioning it between the other two categories.

Table 6, Evaluation Tool Point Allocation for Different Leaf Area Indices

\begin{tabular}{|c|c|c|c|}
\hline Name & Low & Medium & High \\
\hline $\begin{array}{l}\text { Leaf Area } \\
\text { Index }\end{array}$ & $<2.3$ & $2.31-4.62$ & $>4.63$ \\
\hline $\begin{array}{l}\text { Example } \\
\text { Plant } \\
\text { Types }\end{array}$ & $\begin{array}{l}\text { Established sedum, } \\
\text { shrubland }\end{array}$ & $\begin{array}{l}\text { Medium size crops } \\
\text { planted in rows, } \\
\text { isolated trees with } \\
\text { groundcover }\end{array}$ & $\begin{array}{c}\text { complete tree coverage, } \\
\text { shrubs with trees, grass } \\
\text { fields, very dense crop } \\
\text { plantings }\end{array}$ \\
\hline Effects & $\begin{array}{l}\text { Slight reduction in } \\
\text { Tot-N }(\sim 10 \%) \text {, release } \\
\text { of } \mathrm{P} \text {, negligible effect } \\
\text { on } \mathrm{pH} \text { of rainwater }\end{array}$ & $\begin{array}{l}\text { Moderate reduction in } \\
\text { Tot- } \mathrm{N} \text {, decreased } \\
\text { release of } \mathrm{P} \text {, some } \\
\text { effect on } \mathrm{pH} \text { of } \\
\text { rainwater }\end{array}$ & $\begin{array}{l}\text { Significant reduction in Tot- } \\
\mathrm{N}(\sim 75 \%) \text {, decreased or } \\
\text { eliminated release of } \mathrm{P}, \\
\text { neutralization of acidic } \\
\text { rainwater }\end{array}$ \\
\hline Points & 1 & 3 & 5 \\
\hline
\end{tabular}

\subsubsection{Maintenance}

Little information is available that directly quantifies the level of maintenance for green roofs. Wong et al. (2003) indicate that extensive green roofs do not have significantly different maintenance costs than traditional roofs, assuming twice monthly weeding, watering if necessary, and twice yearly inspection of the waterproofing and drainage. These requirements, the authors state, are made up for in decreased maintenance to the waterproofing membrane layers. For a case of an intensive roof covered with $80 \%$ shrubs, a gardener was required attending to the roof on alternating days, working out to the equivalent of one person working part time. The total yearly maintenance cost for this scenario showed a value of $\$ 3.9 / \mathrm{m}^{2} /$ year. Another intensive case was investigated, with mixed tree and grass coverage. Maintenance costs for this case were approximately twice as high as the shrub case, at $\$ 7.5 / \mathrm{m}^{2} /$ year. These values were both significantly higher 
than the anticipated maintenance cost of a traditional built-up flat roof, which only required minor spot repairs and replacement every 20 years. The cost for this worked out to $\$ 1.9 / \mathrm{m}^{2} /$ year. The values used by Bianchini \& Hewage (2012) for green roof maintenance fell between $\$ 0.65 / \mathrm{m}^{2}\left(\$ 0.06 / \mathrm{ft}^{2}\right)$ and $\$ 13.5 / \mathrm{m}^{2}\left(\$ 1.25 / \mathrm{ft}^{2}\right)$, along a standard distribution. The values for all green roof typologies given by Wong et al. (2003) fall well within these bounds.

The work of Proksch (2011) offers a different unit of measurement, as rooftop farms operate in a different manner than extensive and intensive roofs in that they rely largely on volunteers. Case studies presented show rooftop farms with between $74 \mathrm{~m}^{2}\left(800 \mathrm{ft}^{2}\right)$ and $540 \mathrm{~m}^{2}\left(5,800 \mathrm{ft}^{2}\right)$ of cultivated space operate with one full time staff member while being supplemented with volunteers. Brooklyn Grange, a farm with 3,400 $\mathrm{m}^{2}\left(37,000 \mathrm{ft}^{2}\right)$ of cultivated area, is run by a group of five part time partners, and is also supplemented by volunteers. This indicates that the number of staff required does not increase in a linear fashion as the size of project increases.

Generally, increased staff costs are considered a negative, as the owner or manager of the building incurs additional cost. Scenarios exist in which this may not be the case, such as a roof designed for educational use. Rather than create multiple point scales based on different possibilities, the logic of the most common case has been applied here. In scenarios that approach from a different point of view, it is suggested that the weighting of this section be reduced or eliminated.

Based on this information, three categories have been established for use in the evaluation tool. Each represents a different maintenance profile, with Low featuring little to no maintenance as is seen on extensive sedum roofs, Medium representing more simple intensive roofs, and High representing rooftop farms and more attention-hungry intensive roofs. The work of both Proksch (2011) and Wong et al. (2003) served as the guideline for establishing the High category. Based on that information, the category was established as one or more full time staff. 
Table 7, Evaluation Tool Point Allocation for Different Labour Profiles

\begin{tabular}{|l|l|l|l|}
\hline Labour Profile & Low & Medium & High \\
\hline Staff Required & $0,1-2$ yearly check ups & $0.5-1$ full time & $1+$ full time \\
\hline Points & 5 & 2 & 0 \\
\hline
\end{tabular}

\subsubsection{Amenity}

Based on the work of Ichihara \& Cohen (2010), it can be understood that green roofs increase the value of buildings they are installed on. This will vary on a project by project basis, but Ichihara \& Cohen found through investigation of both intensive and extensive roofs, rents were $16.2 \%$ higher on average than buildings that did not feature green roofs. Tomalty \& Komorowski (2010) separated green roofs by type, suggesting that a recreational rooftop garden confers a $20 \%$ increase in value. This category includes both extensive and intensive roofs, and no further distinction is given by the authors. Agricultural roofs are separated into their own category, and are found to provide a 7\% increase in value.

Numbers for extensive and intensive roofs given by Ichihara \& Cohen (2010) and Tomalty \& Komorowski (2010) fall close to one another, with a midpoint of $18.1 \%$. Further distinction between these two typologies was not possible, based on the available literature. As more research is carried out in this area it will become possible to distinguish in a more granular fashion. Tomalty \& Komorowski were the only source to place a value on agricultural roofs, and state the benefit as a $7 \%$ increase.

For this evaluation tool, it is assumed that an increase in value is a positive. To translate these increases in value to the point system of the evaluation tool, the highest increase (18.1\%) was first taken and awarded the maximum number of points. This was applied to both extensive and intensive systems, since they offer the same increase in value. For agricultural systems, which provide a smaller increase in value, the increase, 7\%, was divided by the increase conferred by the other systems, $18.1 \%$. This showed that the increase in value from an agricultural roof was $40 \%$ of that from either of the other two 
systems. The agricultural typology was thus awarded $40 \%$ of the maximum number of points.

Table 8, Evaluation Tool Point Allocation for Different Typologies

\begin{tabular}{|l|c|c|c|}
\hline Typology & Agricultural & Extensive & Intensive \\
\hline Property Value Increase & $7 \%$ & $18.1 \%$ & $18.1 \%$ \\
\hline Points & 2 & 5 & 5 \\
\hline
\end{tabular}

Accessibility is a second characteristic of roofs that affects their amenity. Roofs that people can see up close and use are valued to a higher degree than those that are not (Chiesura, 2004). To this end, a second points category was created for the Amenity section, with a binary field for the user to input whether the roof will be accessible or not. Since accessible roofs offer greater amenity, it was awarded the maximum number of points, and roofs that were not accessible were awarded no points.

Table 9, Evaluation Tool Point Allocation for Accessibility

\begin{tabular}{|l|c|c|}
\hline Accessibility & Yes & No \\
\hline Points & 5 & 0 \\
\hline
\end{tabular}

The third major point of difference among green roof typologies is the ability for agricultural systems to provide produce for consumption by occupants or for sale. In both cases food is being produced and consumed locally. This reduces pollution associated with transportation of food, which, in North America, travels an average of 2,100 kilometers (1,300 miles) before it is consumed (Lacy, 2000, Lapping, 2004).

Generally, intensive roofs are used for vegetable production as the deeper substrates are seen as providing sufficient depth for a wide variety of crops (Proksch, 2011). However, recent work by Whittinghill et al. (2013) has demonstrated that productive farming is 
possible in as little as $10.5 \mathrm{~cm}$ (4 in) of substrate. Thus, this evaluation tool does not assume that deeper substrate is required for yielding produce. This allows this variable to stand independently, meeting one of the high level goals of the evaluation tool of compartmentalization. Maximum points are awarded to roofs that produce food, and none are awarded to those that do not produce. As with accessibility, this is a binary category, with a roof either meeting the goal or not, so no gradations in points have been constructed.

Table 10, Evaluation Tool Point Allocation for Food Production

\begin{tabular}{|l|c|c|}
\hline $\begin{array}{l}\text { Produces } \\
\text { Food? }\end{array}$ & Yes & No \\
\hline Production & $0.84-2.53 \mathrm{~kg} / \mathrm{m}^{2}$ & N/A \\
\hline Points & 5 & 0 \\
\hline
\end{tabular}

\subsubsection{Irrigation}

Effective implementation of irrigation on green roofs is key for their success. Poor irrigation will lead to low vegetation coverage, reducing the roof's amenity and potentially not meeting the City's requirement of $80 \%$ coverage of the designated green roof area after three years (City of Toronto, 2013). Even drought-tolerant species like sedum show significantly better coverage rates when an irrigation system is installed (Rowe et al. 2014, VanWoert et al. 2005a). However, overwatering can have negative effects as well, chiefly by reducing the storm water retention capability of the roof.

The proper irrigation scheme is highly dependent on the type of green roof being considered. For plant beds on the ground, drip irrigation is generally more efficient (Fortier, 2014, Gleik, 2002). This, however, assumes that typical topsoil is being used as a substrate, which differs greatly from many of the substrates used on green roofs. Engineered green roof substrates generally have a high total pore volume. These substrates offer little lateral capillary movement, due to this high porosity. Water 
introduced to the substrate using either surface or sub-surface drip irrigation will flow downward and off the roof, leading to high quantities of wasted water and creating large dry zones between each course of drip pipe (Rowe et al. 2014). In their experiment, Rowe et al. (2014) quantified differences in wastewater among multiple irrigation schemes on green roofs with engineered growth media. Overhead watering was found to perform best, producing an average of $<35 \%$ wastewater, which varied with the water holding capacity of each of the tested media. Drip and sub-surface irrigation showed 67-96\% wastewater, which the authors attribute to the characteristics of the substrate. This resulted in sections of the media being completely dry while other areas became completely saturated very quickly. Overhead irrigation spread water move evenly, wetting all of the media evenly and producing less wastewater as a result. Overall water use was also lower through overhead irrigation, with an average of $47 \%$ less water used compared to surface and sub-surface irrigation methods.

Rooftop farms that do not use an engineered substrate function more in line with the results observed in ground level farms, with drip irrigation offering higher efficiency. No figures specific to green roofs were available, so values from ground level farms have been used here. Hanson et al. (1997) found that drip irrigation required an average of $59 \%$ less water than standard irrigation methods, while Ibragimov et al. (2007) found a value of $32 \%$. The results observed in these studies were used to establish each category for scenarios where regular soil is used. Values for lightweight substrate are established based on the findings of Rowe et al. (2014). The resulting table based on these values is shown below. 
Table 11, Evaluation Tool Point Allocation for Different Watering Schemes

\begin{tabular}{|l|c|c|c|c|c|}
\hline $\begin{array}{l}\text { Watering } \\
\text { Scheme }\end{array}$ & $\begin{array}{c}\text { Lightweight, } \\
\text { Standard Irrigation }\end{array}$ & $\begin{array}{c}\text { Lightweight, } \\
\text { Drip Irrigation }\end{array}$ & $\begin{array}{c}\text { Soil, } \\
\text { Standard } \\
\text { Irrigation }\end{array}$ & $\begin{array}{c}\text { Soil, Drip } \\
\text { Irrigation }\end{array}$ & None \\
\hline $\begin{array}{l}\text { Water } \\
\text { Efficiency }\end{array}$ & $\begin{array}{c}\text { High, } \sim 35 \% \text { waste, } \\
53 \% \text { less use than } \\
\text { lightweight drip }\end{array}$ & $\begin{array}{c}\text { Low, } \sim 67-96 \% \\
\text { waste }\end{array}$ & Moderate & $\begin{array}{c}\text { High, }>30-75 \% \\
\text { less use than } \\
\text { standard }\end{array}$ & N/A \\
\hline Points & 3 & 0 & 1 & 3 & 5 \\
\hline
\end{tabular}

\subsection{User Input}

To use this evaluation tool, it is recommended that the user have a conceptual idea of their design or the options they are considering. This will expedite the use of the tool, and allow the user to quickly obtain a result. The evaluation tool gives green roof designers an easily digestible set of performance metrics in addition to an overall result, and, if results are deemed unsatisfactory, demonstrates alternatives that can be implemented. However, the evaluation tool is constructed such that the performance of each design decision is surfaced, allowing the tool to be used in an exploratory fashion as well. If the user is early in the design stage, many options can be investigated. In this scenario, the user might not come to the evaluation tool with particular options in mind. Such a scenario is easily accommodated, though it will require the user to spend more time building different scenarios.

The first step in making use of the evaluation tool tool is for the user to determine the relative importance of each criteria and variable. Agency in this aspect has been given to the user, allowing them to make a judgment based on what is most significant for their project. Each project has its own goals, and accommodating these variances between projects makes the tool more widely usable. The user must distribute 100 points among the five criteria, dependent on the relative importance of each to their project. To complete the weighting, 100 points must also be distributed between the variables of 
Water Runoff Quantity, and an additional 100 points between the variables of Amenity. Before proceeding, each box labelled "Remaining Weighting Points" should read "0."

The final step for the user is in the "Selection" column, where the user selects, from a drop-down menu, an option from the "Design Option" column. This causes the tool to display values both in the "Criteria Points" and "Weighted Points" columns. The value in the "Criteria Points" column simply displays the score of the selected option for easy reference. The value in the "Weighted Points" column is a sum of each of the base point values in the criteria, taking into account the weighting assigned earlier by the user. This total is an indication of how effective the designer's selections are at meeting the goals of that criteria that they have set, as interpreted through the weighting they have assigned. The rest of the work is handled by the tool, which then takes a sum of each value in the "Weighted Points" column to yield an overall Point Total at the bottom right of the tool. This is a score out of five, and is a sum of the total of all of the weighted points totals. This value indicates how effective the roof is at meeting all of the goals of the project, which is interpreted based on the weightings they have input.

\subsection{Evaluation tool}

The tool has been developed in Microsoft Excel. The ubiquity of this software confers broad reach. Building the tool in Excel also results in simplicity, allowing even those with little technical computer knowledge to interact with the tool. The offline nature of Excel means that the tool can also be used without a connection to the Internet, allowing it to be downloaded and used anywhere.

An example screenshot of the tool is shown below in Figure 1. This screenshot shows the tool with all user input having been carried out, as can be seen through the presence of values in the solid green columns. The evaluation tool has been designed such that the user need handle only columns marked in saturated green. A column of any other color indicates that no user input is required there. 


\begin{tabular}{|c|c|c|c|c|c|c|c|c|c|c|}
\hline Criteria & $\begin{array}{c}\text { Criteria } \\
\text { Weighting }\end{array}$ & Variable & $\begin{array}{l}\text { Varlable } \\
\text { Weighting }\end{array}$ & Design Option & Effects & Example & Points & Selection & $\begin{array}{l}\text { Criteria } \\
\text { Points }\end{array}$ & $\begin{array}{l}\text { Welghted } \\
\text { Points }\end{array}$ \\
\hline \multicolumn{11}{|c|}{ D. } \\
\hline \multirow{5}{*}{ Water Runoff } & \multirow{5}{*}{0} & \multirow{5}{*}{ Substrate Depth } & & $<100 \mathrm{~mm}$ & $<58 \%$ storm water retention & - & 1 & \multirow{5}{*}{$4100 \mathrm{~mm}$} & \multirow{5}{*}{1} & \multirow{5}{*}{0.0} \\
\hline & & & & $101-150 \mathrm{~mm}$ & 58-63\% storm water retention & - & 2 & & & \\
\hline & & & & $151-300 \mathrm{~mm}$ & 63.77\% storm water retention & - & 3 & & & \\
\hline & & & & $301-534 \mathrm{~mm}$ & 77-99\% storm water retention & - & 4 & & & \\
\hline & & & & $2535 \mathrm{~mm}$ & $100 \%$ storm water retention & - & 5 & & & \\
\hline \multirow{7}{*}{$\begin{array}{l}\text { Water Runoff } \\
\text { Quality }\end{array}$} & \multirow{7}{*}{0} & \multirow{3}{*}{ Fertilizer Type/Use } & \multirow{3}{*}{0} & Soluble & Significant impact on N-P-K in effluent & - & 0 & \multirow{3}{*}{ Soluble } & \multirow{5}{*}{0} & \multirow{7}{*}{0.0} \\
\hline & & & & $\begin{array}{l}\text { Controlled-Release } \\
\end{array}$ & Small impact on N-P-K in effluent & - & 3 & & & \\
\hline & & & & No Fertilizer & No adverse effect on effiuent & - & 5 & & & \\
\hline & & \multirow{3}{*}{ Leaf Area Index } & \multirow{3}{*}{0} & Low, $<2.3$ & $\begin{array}{l}\text { Slight reduction in Tot- } \mathrm{N}(\sim 10 \%) \text {, release of } \\
\mathrm{P} \text {, negligible impact on pH of rainwater }\end{array}$ & Sedum, shrubland & 1 & \multirow{4}{*}{ Low, 2.3} & & \\
\hline & & & & Medium, 2.31-4.62 & $\begin{array}{l}\text { Moderate reduction in Tot-N, low release of } \\
P, \text { some neutralization of acid in rainwater }\end{array}$ & $\begin{array}{l}\text { Medium size crops planted in } \\
\text { rows, isolated trees with } \\
\text { groundcover }\end{array}$ & 3 & & & \\
\hline & & & & $\mathrm{High},>4.63$ & $\begin{array}{l}\text { Significant reduction in Tot- } N(\sim 75 \%) \text {, } \\
\text { decreased or eliminated release of } \mathrm{P} \text {, } \\
\text { significant neutralization of acid in rainwater }\end{array}$ & $\begin{array}{l}\text { Complete tree cover, shrubs } \\
\text { with trees, tall grass fields, } \\
\text { very dense crop plantings }\end{array}$ & 5 & & \multirow{2}{*}{1} & \\
\hline & & \begin{tabular}{|l} 
Remaining Weighting Points \\
\end{tabular} & 100 & & & & & & & \\
\hline \multirow{3}{*}{ Maintenance } & \multirow{3}{*}{0} & \multirow{3}{*}{ Labour Requirement } & & Low & Negligible cost & $\begin{array}{l}\text { No maintenance, } 1-2 \text { yeariy } \\
\text { check ups }\end{array}$ & 5 & \multirow{3}{*}{ Low } & \multirow{3}{*}{5} & \multirow{3}{*}{0.0} \\
\hline & & & - & Medium & Moderate cost & $0.5-1$ full time staff & 2 & & & \\
\hline & & & & High & High cost & $\begin{array}{c}1+\text { full time staff, } \\
\text { supplemental volunteer labor }\end{array}$ & 0 & & & \\
\hline \multirow{7}{*}{ Amenity } & \multirow{7}{*}{0} & \multirow{3}{*}{ Property Value Increase } & \multirow{3}{*}{0} & Agricultural & $7 \%$ & - & 2 & & & \\
\hline & & & & Intensive & $18.1 \%$ & - & 5 & Fagricultural & 2 & \\
\hline & & & & Extensive & $18.1 \%$ & - & 5 & & & \\
\hline & & Accessible & 0 & Yes & Can be used by occupants & - & 5 & Yes & 5 & 0.0 \\
\hline & & 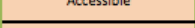 & 0 & № & & - & 0 & res & 3 & \\
\hline & & Food Production & 0 & Yes & $0.84-2.53 \mathrm{~kg}$ produce $/ \mathrm{m}^{\wedge} 2$ & - & 5 & & & \\
\hline & & Remaining Weighting Points & 100 & No & No produce & - & 0 & No & 0 & \\
\hline & & & & $\begin{array}{l}\text { Lightweight Media, } \\
\text { Standard Irrigation }\end{array}$ & $\begin{array}{l}\text { High efficiency, } 35 \% \text { waste, } 53 \% \text { less use } \\
\text { than Lightweight Media, Drip Irrigation }\end{array}$ & - & 3 & & & \\
\hline & & & & $\begin{array}{l}\text { Lightweight Media, Drip } \\
\text { Irrigation }\end{array}$ & Low effeciency, 67-96\% waste & - & 0 & $\begin{array}{l}\text { Lightweight } \\
\text { Meda, }\end{array}$ & & \\
\hline Irrigation & ${ }^{\circ}$ & Watering Scheme & & Soil, Overhead Irrigation & Moderate efficiency & - & 1 & Standard & 3 & 0.0 \\
\hline & & & & Soil, Orip Irrigation & $\begin{array}{l}\text { High efficiency, ₹30-75\% less water use than } \\
\text { Soil, Overhead Irrigation }\end{array}$ & - & 3 & Irrigation & & \\
\hline & & & & None & & - & 5 & & & \\
\hline Remaining & & & & & & & & & & \\
\hline $\begin{array}{c}\text { Weighting } \\
\text { Points }\end{array}$ & 100 & & & & & & & & & 0.0 \\
\hline
\end{tabular}

Figure 1, Evaluation Tool Overview 


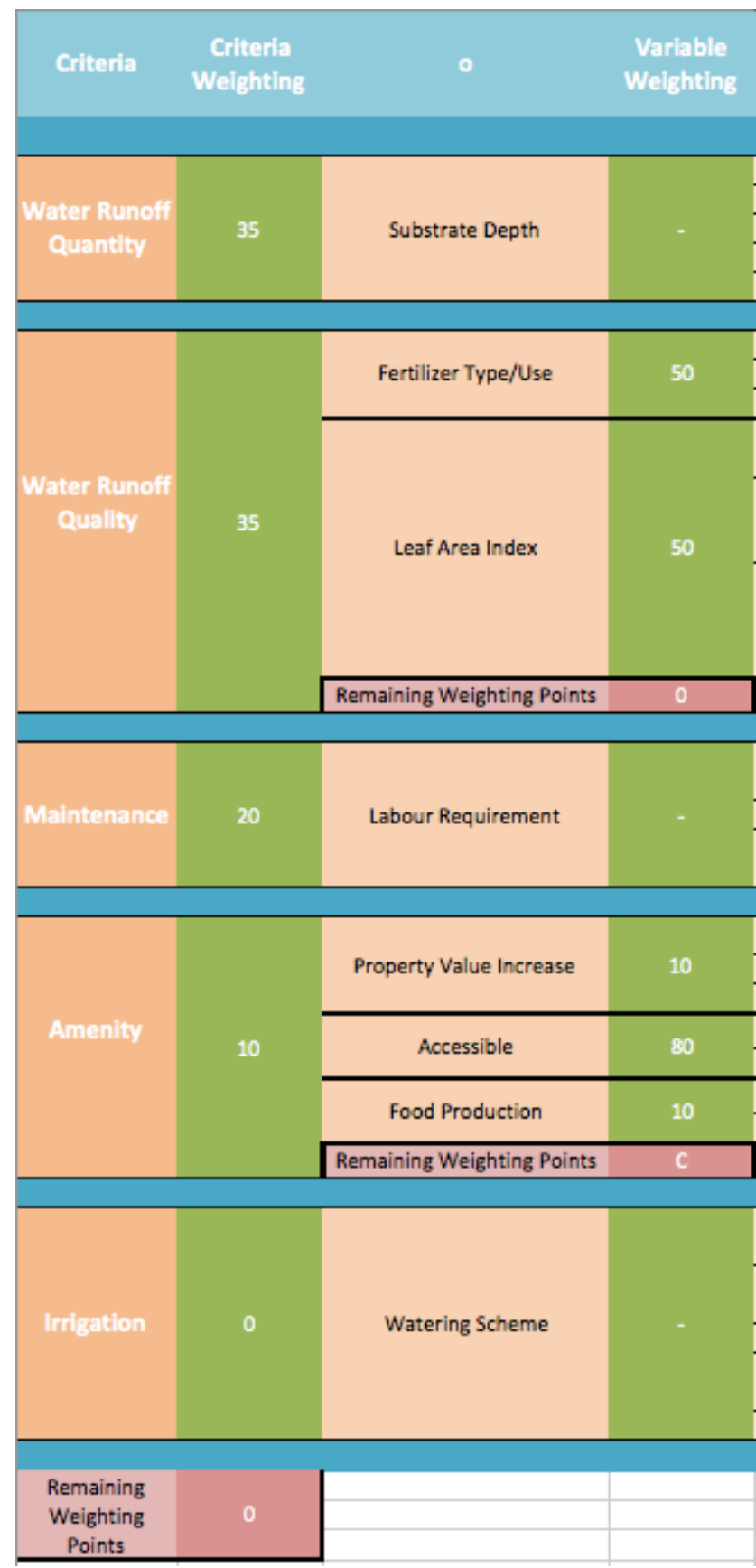

Figure 2, Case Study 1 Weightings

\subsection{Case Studies}

To demonstrate use of the evaluation tool, two hypothetical case studies are described here for illustrative purpose. These case studies serve to both showcase how a user could use the evaluation tool, as well as showcasing the flexibility of the system to accommodate multiple scenarios or user types.

\subsubsection{Case Study One}

User 1 is a green roof designer working on a green roof project that is planned as an accessible roof on an educational building to be be used by students and faculty. The client is chiefly concerned with storm water, both in terms of quality and quantity, as they know that their area of the city still uses combined storm water and sewage that results in combined storm water overflow events (CSO) due to mixing between sewage and storm water during heavy rain events. This is the priority over all other concerns. If

possible, the client would like to minimize ongoing costs. The client has indicated that they are willing to consider any typology. The building has been designed to utilize recycled grey water and air conditioner condensate for irrigation, so irrigation efficiency is not very important to them. 


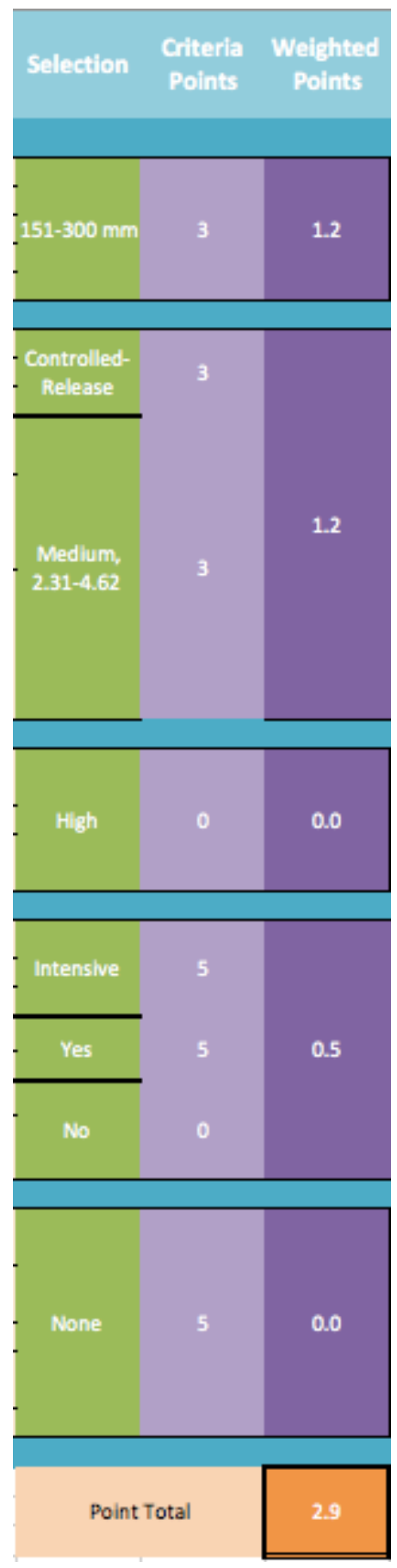

Figure 3, Case Study 1 Results

User 1 brings this information to the evaluation tool, deciding that the weighting of the criteria Water Runoff Quantity and Water Runoff Quality should be highest, followed by Maintenance, then Amenity, and that. Irrigation will be eliminated from consideration by applying zero weighting points to that criterion.

Within Water Runoff Quality, User 1 applies even weighting to each variable, as neither has been decided as being more important at this point. For Amenity, however, she inputs a high value, 80 points, for the Accessible variable, as this is a non-negotiable point, and is considered very important by her client. The remaining 20 points are applied evenly.

User 1 has two ideas about the type of roof she would like to use on this project. The first is an extensive roof designed as a walkable garden featuring a mix of taller species and lower growing plants.

User 1 begins with the Water Runoff Quantity criteria, selecting the "151-300 mm" category, as the plant selection for this scenario calls for a substrate depth of at least 200 $\mathrm{mm}$, though the building could support up to $400 \mathrm{~mm}$. Next is the Water Runoff Quality criteria. User 1 intends to use controlled-release fertilizer on this roof, and estimates that the leaf area index will be between 3 and 3.5, when averaged across the roof, based on the species she has selected. She selects the appropriate categories for each. For Maintenance, she knows that because this garden features many ornamentals and is intended as a showpiece, the labour requirement will be high. She selects the High option to represent this. For the Amenity criteria variables, User 1 knows that this roof will be intensive, accessible, and not produce food, 


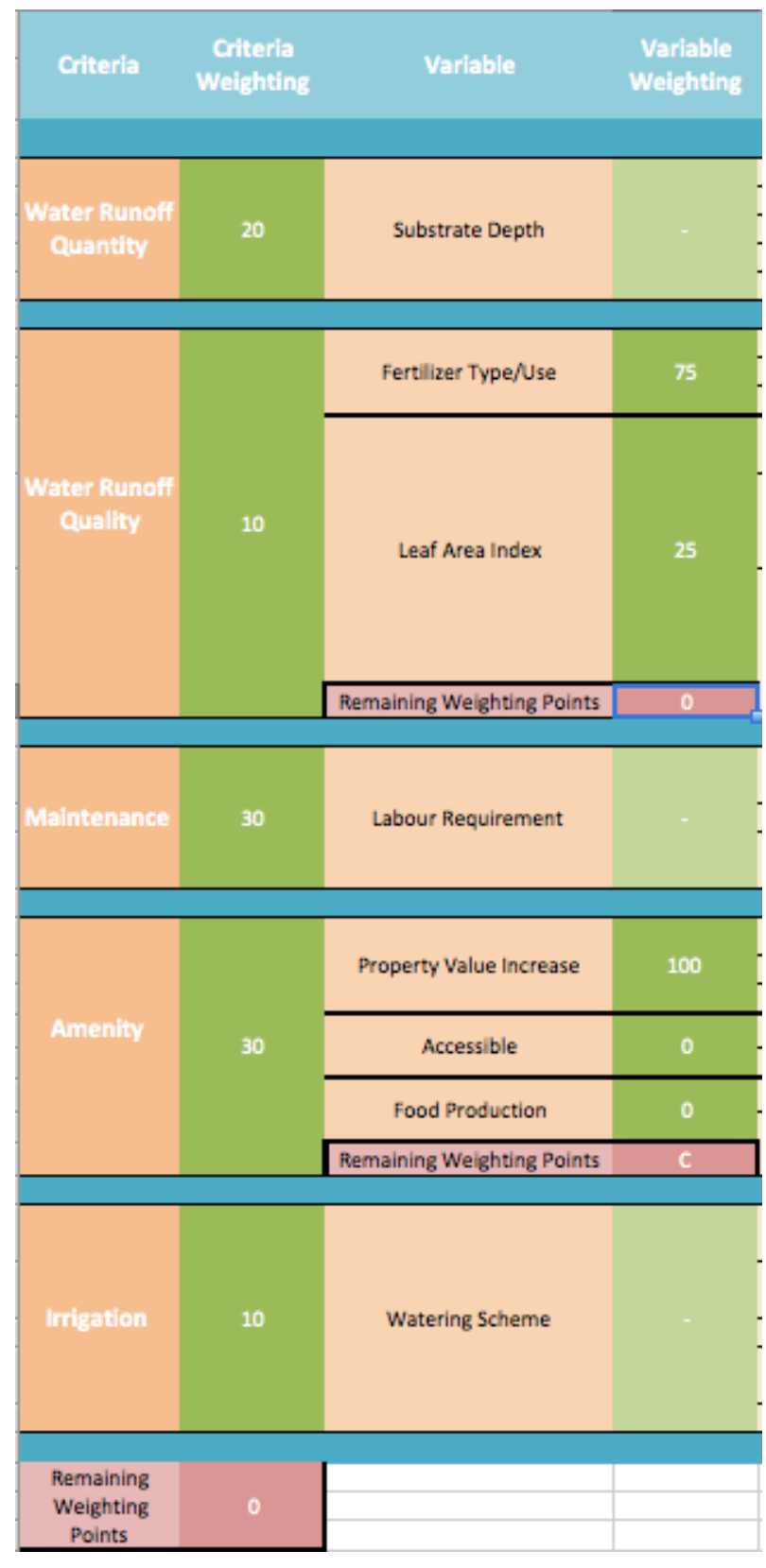

Figure 4, Case Study 2 Weightings

so she selects these options. Since the Irrigation criteria was assigned 0 points for weighting, it is disregarded.

This yields an overall Point Total of 2.9, a decent result, but not as high as User 1 had hoped. She decides to enter the second scenario to see if that offers results closer to what her client is hoping to accomplish.

The second design she is considering is a roof featuring a mix of trees, tall shrubs, and high meadow-like grasses. This design will require a deeper substrate and have a higher leaf area index thanks to the inclusion of trees and tall grasses.

The selected tree species will require a substrate depth of around $550 \mathrm{~mm}$, allowing her to select the deepest option in the Substrate Depth variable of Water Runoff Quantity. She adjusts Leaf Area Index variable to the High option to account for the more dense plants in this scenario. Maintenance will not be changed, nor will any of the variables included in the Amenity category.

With these changes input, the overall Point Total has increased to 4.1 , a significantly better score than with the first scenario. User 1 decides to select the second option for her project as a result. 


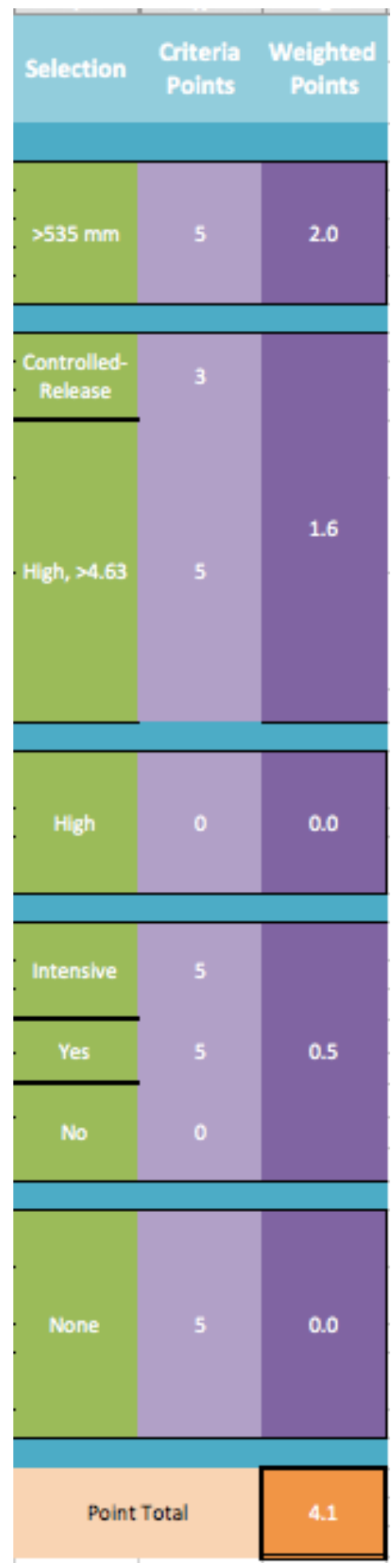

Figure 5, Case Study 2 Weightings

\subsubsection{Case Study 2}

User 2 is planning a green roof retrofit for his office building. The structural engineer has determined that the building can only support the load of a system with $120 \mathrm{~mm}$ of substrate. This limits User 2 to an extensive system, which works well for him, since he is not interested in paying someone to perform maintenance or to fertilize. The design of the building means that the roof will not be accessible. User 2 is interested in increasing the overall amenity of his building so that he can increase his rents by adding a "green" feature that will separate him from his competitors' buildings. To this end he is interested in being able to say that he is reducing the storm water coming off of his building, although this is not as important to him as the maintenance and amenity concerns.

Looking at the Criteria Weighting column, User 2 grants 20 points to Water Runoff Quantity and 10 points to Water Runoff Quality. The things he is most concerned about, Maintenance and Amenity are awarded 30 points. Irrigation is given the remaining 10 .

For the variables within Water Runoff Quality, User 2 allocates 75 points to Fertilizer Type/Use, as it is important to him that the roof not be contributing negatively to the outgoing water quality. The only variable he considers important within Amenity is the increase in his property value, as this is a driving force behind his decision to go forward with this plan. 


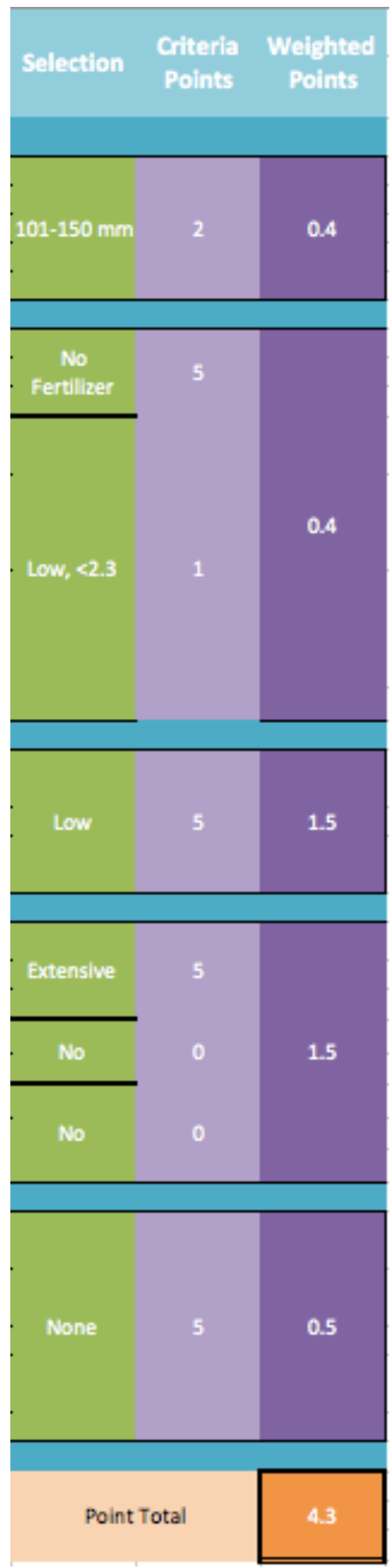

Figure 6, Case Study 2 Revised Results
With these in place, User 2 moves on to inputting design options. He knows that the maximum substrate depth is $120 \mathrm{~mm}$ based on the structural engineer's report, so he selects 100-150 mm for Substrate Depth. For Water Runoff Quality, User 2 has decided that no fertilizer will be applied to the roof after establishment, and he will be using hardy sedum species so that the minimum possible maintenance is required. Both of the appropriate selections are made based of these decisions. Because he has opted for a sedum roof that requires minimal maintenance, the Low option is selected for the Labour Requirement variable. Under Amenity, User 2 selects the Extensive typology, and disregards the other two variables, as their weighting has been set to 0 . The final category is Irrigation, in which he selects the option for None, as no irrigation will be installed on the roof to keep costs down.

The resulting score is 4.3 , showcasing that this roof is an excellent choice for User 2 to move ahead with. The roof offers a good combination of decent storm water reduction, requiring next to no maintenance, and offering a significant increase to his property's value. These are User 2's primary concerns, and they are all addressed well. 


\section{Conclusions}

\subsection{Overall Conclusions}

Green roofs offer a way to make use of space in the urban environment that is traditionally overlooked. The benefits are wide, and are significantly impacted by the choices of the designer. By creating an evaluation tool for the evaluation of green roofs, future designers are given a tool that allows them to compare various options and evaluate their design choices, backed by data, rather than rules of thumb or intuition.

Use of this tool and application to case studies has demonstrated that it is difficult to meet all of the goals that people have for green roofs. This is showcased by the difficulty of obtaining a high score, particularly when the user has many goals at once. Often trying to meet one goal or working within certain constraints makes it difficult to meet all of the goals of a project.

At the inception of this project the goal was as described in the preceding paragraphs, but in the execution another benefit became apparent - this work has served to highlight the areas of green roofs that still require attention from the research community. The areas of amenity, irrigation, and maintenance have received little attention, along with the topic of rooftop agriculture in general. This is understandable, as these topics are more difficult to research than those such as storm water quantity and quality, which are easy to measure and test through experiments. Green roofs are also seen largely as a means of reducing storm water runoff, and consequently, much research has focused on this topic. Again, this is sensible, as green roofs are indeed an excellent option for helping to solve the issues caused by storm water in urban spaces, which are significant. However, this is also the fact that indicates that other areas should receive attention: the efficacy of green roofs in alleviating storm water pressures is indisputable. It has been proven. In striving to understand a thing, it should be considered from all angles, each aspect being evaluated and tested to determine the optimal solution. 
One significant topic for future research is evaluation of the increase in value seen among each typology. The majority of published works on the topic utilize estimations based on other, similar cases. For example, rooftop agriculture is assumed to confer the same value as an ground-level community garden, and intensive and extensive roofs are assumed to be worth the same as a nearby ground level park. A major hurdle for green roofs to overcome is their high initial cost relative to traditional roofing options. Investigation into the potential monetary benefits of green roofs may offer another perspective that will assist in increasing their adoption.

Additionally, rooftop agriculture in general has received little attention. These projects, while still relatively rare, do exist, and are becoming more popular as demonstrated by the recent publishing of studies on the topic. There are significant differences between a walkable rooftop garden, a roof covered with sedum mats, and a rooftop agriculture project. Quantifying these differences is important, and is, at present, difficult. An attempt has been made here, and as more research on this topic is carried out, it will be possible to perform more granular evaluation and comparison.

\subsection{Future Evaluation tool Improvements}

This evaluation tool has been designed not a fixed work, but as a tool that can evolve and grow as better, more complete information becomes available. Green roofs are a relatively new area of research, particularly in North America. As the body of knowledge continues to grow, it will be possible to hone and improve this evaluation tool. Future work can expand upon the foundation laid here, adding criteria, refining variables, and tuning options within those variables.

Each of the potential criteria identified in Section 3.1 are relevant to the overall performance of green roofs. Due to the scope and timeline of this project, it was not possible to investigate each of these to a satisfactory degree. Those that were found to be the most relevant, as well as those that offered high variability in performance between each of the typologies were included in this first version of the evaluation tool. Future 
work could expand upon the evaluation tool by building it to include these criteria, allowing for a fuller understanding of green roofs along these lines.

It is also likely that additional criteria that are not discussed here could be identified. Issues such as biodiversity, animal habitat creation, potential for use of recycled materials are examples of some of these criteria that are discussed in a number of papers reviewed during the literature review in this work.

The decision to maintain the compartmentalized structure of the evaluation tool allows for the easy addition or removal of one piece or another. This structure, however, also means that users can input conditions that are not possible, leading to deceptive results. For example, a user could, if they wished, input a substrate depth of $<100 \mathrm{~mm}$, High Leaf Area Index, Low Labour Requirement, Agricultural Typology, and No Irrigation. Such a scenario seems unlikely to be successful, but it is possible to build such a scenario within the confines of the evaluation tool at present. This decision was made to account for the possibility of future developments or improved systems, as discussed in some of the subsections of Section 4.4. This was an issue throughout development of the evaluation tool, but the ability to add and remove criteria was held to be more important than the possibility of user error. In a future version of the evaluation tool that includes additional criteria or variables, it may be helpful or necessary to implement a system that restricts choices that are mutually exclusive. At present, there are no explicit conflicts, though, as discussed above, it is possible to create scenarios that are at best, unlikely to succeed. Accounting for these possibilities would make the evaluation tool stronger, overall. 


\section{References}

ASHRAE. (2008). International climate zone definitions. Retireved from https://www.ashrae.org/File\%20Library/docLib/Public/20081111_CZTables.pdf

Aster, D., \& Mecklinger, S. (2010). Toronto's green roof construction standard. Paper presented at Cities Alive: Eighth Annual Green Roof and Wall Conference, Vancouver, Canada.

Berndtsson, J.C. (2010). Green roof performance towards management of runoff water quantity and quality: A review. Ecological Engineering, 36(4), 351-360. doi: 10.1016/j.ecoleng.2009.12.014

Berndtsson, J.C., Emilsson, T., \& Bengtsson, L. (2006). The influence of extensive vegetated roofs on runoff water quality. Science of the Total Environment, 355(1-3), 4863. doi:10.1016/j.scitotenv.2005.02.035

Berndtsson, J.C., Bengtsson, L., \& Jinno, K. (2009). Runoff water quality from intensive and extensive vegetated roofs. Ecological Engineering, 35, 369-380. doi:10.1016/j.ecoleng.2008.09.020

Bianchini, F. \& Hewage, K. (2012). Probabilistic social cost-benefit analysis for green roofs: A lifecycle approach. Building and Environment, 58, 152-162. doi: 10.1016/j.buildenv.2012.07.005

Blank, L., Vasl, A., Levy, S., Grant, G., Kadas, G., Dafni, A., \& Blaustein, L. (2013). Directions in green roof research: A bibliometric study. Building and Environment, 66, (23-28). doi: 10.1016/j.buildenv.2013.04.017

Blanusa, T., Monteiro, M., Fantozzi, F., Vysini, E., Li, Y., \& Cameron, R.W.F. (2013). Alternatives to sedum on green roofs: Can broad leaf perennial plants offer better 'cooling service'? Building and Environment, 59, 99-106. doi:10.1016/j.buildenv.2012.08.011

Brouwer, C., \& Heibloem, M. (1986). Irrigation water management. Rome, Italy: Food and Agriculture Organization of the United Nations. Retrieved from http://www.fao.org/docrep/s2022e/s2022e02.htm

Bucheli, T.D., Müller, S.R., Heberle, S., \& Schwarzenbach, R.P. (1998). Occurrence and behavior of pesticides in rainwater, roof runoff, and artificial stormwater infiltration. Environmental Science \& Technology, 32(22), 3457-3464. doi: 10.1021/es980317n

Canada Mortgage and Housing Corporation. (2006). Green roofs: A resource manual for municipal policy makers. Retrieved from http://www.cmhcschl.gc.ca/odpub/pdf/65255.pdf?lang=en

Carter, T., \& Jackson, C.R. (2007) Vegetated roofs for stormwater management at multiple spatial scales. Landscape and Urban Planning, 80(1-2), 84-94. doi: 10.1016/j.landurbplan.2006.06.005 
Chiesura, A. (2004). The role of urban parks for the sustainable city. Landscape and urban planning, 68(1), 129-138. doi: 10.1016/j.landurbplan.2003.08.003

City of Toronto. (2013). Toronto municipal code: Chapter 492, green roofs.

City of Toronto. (2015a). About stormwater. Retrieved from http://www1.toronto.ca/wps/portal/contentonly?vgnextoid=b99807ceb6f8e310VgnVCM1 0000071d60f89RCRD\&vgnextchannel=094cfe4eda8ae310VgnVCM10000071d60f89RC $\mathrm{RD}$

City of Toronto. (2015b). Economic dashboard - Annual summary, 2015. Retrieved from http://www.toronto.ca/legdocs/mmis/2015/ed/bgrd/backgroundfile-76322.pdf

City of Toronto. (2015c). Economic indicators: May 2015. Retrieved from http://www1.toronto.ca/static_files/economic_development_and_culture/docs/Economic \%20indicators/economic_indicators.pdf

Coutts, A.M., Daly, E., Beringer, J., \& Tapper, N.J. (2013). Assessing practical measures to reduce urban heat: Green and cool roofs. Building and Environment, 70, 266-276. doi:10.1016/j.buildenv.2013.08.021

Dunnett, N., \& Kingsbury, N. (2004). Planting green roofs and living walls. Portland, OR: Timber Press.

Dobrian, J. (2014). Changing tastes fuel amenities race. Journal of Property Management, 79(2), 16-22.

Emilsson, T., \& Rolf, K. (2005). Comparison of establishment methods for extensive green roofs in southern Sweden. Urban Forestry \& Urban Greening, 3, 103-111. doi:10.1016/j.ufug.2004.07.001

Emilsson, T., Berndtsson, J.C., \& Mattsson, J.E., \& Rolf, K. (2007). Effect of using conventional and controlled release fertiliser on nutrient runoff from various vegetated roof systems. Ecological Engineering, 29(3), 260-271. doi: 10.1016/j.ecoleng.2006.01.001

Environment Canada. (2015). Canadian Climate Normals 1970-2000 Station Data. Retrieved from http://climate.weather.gc.ca/climate_normals/results_e.html?stnID=5051\&autofwd=1

Faulkner, R. (2014). The nature and benefits of drip irrigation. Outlooks on Pest Management, 25(4), 278-284. doi:http://dx.doi.org/10.1564/v25_aug_07

Fortier, J-M. (2014). The market gardener: A successful grower's handbook for smallscale organic farming. Gabriola Island, BC: New Society Publishers.

Gagliano, A., Detommaso, M., Nocera, F., \& Evola, G. (2015). A multi-criteria methodology for comparing the energy and environmental behavior of cool, green and traditional roofs. Building and Environment, 90, 71-81. doi: 10.1016/j.buildenv.2015.02.043 
Getter, K.L., \& Rowe, D.B. (2006). The role of extensive green roofs in sustainable development. HortScience, 41(5), 1276-1285.

Getter, K.L., \& Rowe, D.B. (2008). Media depth influences sedum green roof establishment. Urban Ecosystems, 11(4), 361-372. doi: 10.1007/s11252-008-0052-0

Getter, K.L., Rowe, D.B., \& Andresen, J.A. (2007). Quantifying the effect of slope on extensive green roof stormwater retention. Ecological Engineering, 31, 225-231. doi: 10.1016/j.ecoleng.2007.06.004

Getter K.L, Rowe, D.B., Robertson, G.P., Cregg, B.M., \& Andresen, J.A. (2009). Carbon sequestration potential of extensive green roofs. Environmental Science \& Technology, 43(19), 7564-7570. doi:10.1021/es901539

Gleik, P.H. (2002). Water management: Soft water paths. Nature, 418, 373. doi:10.1038/418373a

Green Roofs for Healthy Cities (2015). Annual green roof industry survey for 2015. Toronto, ON: Canada. Retrieved from http://www.greenroofs.org/resources/GreenRoofIndustrySurveyReport2014.pdf

Griffin, W. N. (2014). Extensive green roof substrate composition: Effects of physical properties on matric potential, hydraulic conductivity, plant growth, and stormwater retention in the mid-atlantic (Order No. 3682432). Available from ProQuest Dissertations \& Theses A\&I; ProQuest Dissertations \& Theses Global. (1658108657).

Gulliver, J.S., Erickson, AJ., \& Weiss, P.T. (2010). Stormwater treatment: Assessment and maintenance. Minneapolis, MN: University of Minnesota, St. Anthony Falls Laboratory.

Guo, Y., Zhang, S., \& Liu, S. (2014). Runoff reduction capabilities and irrigation requirements of green roofs. Water Resource Management, 28, 1363-1378. doi: $10.1007 / \mathrm{s} 11269-014-0555-9$

Gussow, J.D. (1999). Dietary guidelines for sustainability: Twelve years later. Journal of Nutrition Education, 31(4), 194-200. doi: 10.1016/S0022-3182(99)70441-3

Hamdy, A. (2007). Water use efficiency in irrigated agriculture: An analytical review: WASAMED project. CIHEAM, 57, 9-19.

Hanson, B.R., Schwankl, L.J., Schulback, K.F., \& Pettygrove, G.S. (1997). Agricultural Water Management, 33, 139-157. doi: 10.1016/S0378-3774(96)01289-9

Ibragimov, N., Evett, S.R., Esanbekov, Y., Kamilov, B.S., Mizaev, L., \& Lamers, J.P.A. (2007). Water use efficiency of irrigated cotton in Uzbekistan under drip and furrow irrigation. Agricultural Water Mangement, 90, 112-120. doi: 10.1016/j.agwat.2007.01.016

Ichihara, K., \& Cohen, J.P. (2010). New York City property values: What is the impact of green roofs on rental prices? Letters in Spatial and Resource Sciences, 4(1), 21-30. doi:10.1007/s12076-010-0046-4 
Jonckheere, I., Fleck, S., Nackaerts, K., Muys, B., Coppin, P., Weiss, M., \& Baret, F. (2004). Review methods for in situ leaf area index determination: Part 1. Theories, sensors, and hemispherical photography. Agricultural and Forest Meteorology, 121(1-2), 19-35. doi:10.1016/j.agrformet.2003.08.027

Kohler, M., Schmidt, M., Grimme, F.W., Laar, M., Paiva, V.L., \& Tavares, S. (2002). Green roofs in temperate climates and in the hot-humid tropics - Far beyond the aesthetics. Environmental Management and Health, 13(4), 382-391.

Knut, V., Smyrnova, Y., Klæboe, R., Hornikx, M., \& Mosslemi, M. (2012). Valuation of green walls and green roofs as soundscape measures: Including monetized amenity values together with noise-attenuation values in a cost-benefit analysis of a green wall affecting courtyards. International Journal of Environmental Research and Public Health, 9(11), 3770-3788.

Lacy, W.B. (2000). Empowering communities through public work, science, and local food systems: Revisiting democracy and globalization. Rural Sociology, 65(1), 3-26.

Lapping, M.B. (2004). Toward the recovery of the local in the globalizing food system: The rold of alternative agricultural and food models in the US. Ethics, Place, and Environment: A Journal of Philosophy \& Geography, 7(3), 141-150. doi: $10.1080 / 1366879042000332943$

Lee, K.E., Williams, K.J.H., Sargent, L.D., Farrell, C., \& Williams, N.S. (2014). Living roof preference is influenced by plant characteristics and diversity. Landscape and Urban Planning, 122, 152-159. doi:10.1016/j.landurbplan.2013.09.011

Mentens, J., Raes, D., \& Hermy, M. (2006). Green roofs as a tool for solving the rainwater runoff problem in the urbanized $21^{\text {st }}$ century? Landscape and urban planning, 77(3), 217-226. doi: 10.1016/j.landurbplan.2005.02.010

Molineux, C.J., Fentiman, C.H., \& Gange, A.C. (2009). Characterising alternative recycled waste materials for use as green roof growing media in the U.K. Ecological Engineering, 35(10), 1507-1513. doi: 10.1016/j.ecoleng.2009.06.010

Monterusso, M.A., Rowe, D.B., \& Rugh, C.L. (2005). Establishment and persistence of sedum spp. and native taxa for green roof applications. HortScience, 40(2), 391-396.

Oak Ridge National Laboratory. (2001). Global leaf area index data from field measurements, 1932-2000 [Data file]. Available from https://daac.ornl.gov/VEGETATION/lai_des.html

Ontario Ministry of Agriculture, Food, and Rural Affairs. (2009). Soybeans: Planting and crop development. Retrieved from http://www.omafra.gov.on.ca/english/crops/pub811/2planting.htm

Ontario Ministry of Agriculture, Food, and Rural Affairs. (2015). Ontario agri-food trade by commodity type 2004 - 2014. Retrieved from http://www.omafra.gov.on.ca/english/stats/trade/commod.htm

Peck, S.W., Callaghan, C., Kuhn, M.E., Bass, B. (1999). Greenbacks from green roofs: Forging a new industry in Canada. 
Peters, C.J., Bills, N.L., Lembo, A.J., Wilkins, J.L., \& Fick, G.W. (2008). Mapping potential foodsheds in New York state: A spatial model for evaluating the capacity to localize food production. Renewable Agriculture and Food Systems, 24(1), 72-84. doi:10.1017/S1742170508002457

Pocock, M.J.O., Evans, D.M., \& Memmott, J. (2010). The impact of farm management on species-specific leaf area index (LAl): Farm-scale data and predictive models. $\begin{array}{llll}\text { Agriculture, Ecosystems, } \quad \& \quad \text { Envrionment, 135(4), } & \text { 279-287. }\end{array}$ doi:10.1016/j.agee.2009.10.006

Proksh, G. (2011). Urban rooftops as productive resources. Architectural Resource Centers Consortium Journal, 497-509.

Razzaghmanesh, M., \& Beecham, S. (2014). The hydrological behaviour of extensive and intensive green roofs in a dry climate. Science of the Total Environment, 499, 284296. doi:10.1016/j.scitotenv.2014.08.046

Roehr, D \& Primeau, S. (2010). Are green roofs always "green?" A green roof decisionsupport tool. Paper presented at Cities Alive: Eighth Annual Green Roof and Wall Conference, Vancouver, Canada.

Rosen, S. (1974). Hedonic prices and implicit markets: Product differentiation in pure competition. Journal of Political Economy, 82(1), 34-55.

Rowe, D.B. (2011). Green roofs as a means of pollution abatement. Environmental Pollution, 159, 2100-2110.

Rowe, D.B., Kolp, M.R., Greer, S.E., \& Getter, K.L. (2014). Comparison of irrigation efficiency and plant health of overhead, drip, and sub-irrigation for extensive green roofs. Ecological Engineering, 34, 306-313. doi:10.1016/j.ecoleng.2013.12.052

Simmons, M.T., Gardiner, B., Windhager, S., \& Tinsley, J. (2008). Green roofs are not created equal: The hydrologic and thermal performance of six different extensive green roofs and reflective and non-reflective roofs in a sub-tropical climate. Urban Ecosystems, 11, 339-348. doi: 10.1007/s11252-008-0069-4

Speak, A.F., Rothwell, J.J., Lindey, S.J., \& Smith, C.L. (2013). Rainwater retention runoff on an aged green roof. Science of the Total Environment, 461 \& 462, 28-38. doi:10.1016/j.scitotenv.2013.04.085

Statistics Canada. (2015). Area, production and farm value of specified commercial vegetable crops, Ontario, 2013-2014. Retrieved from http://www.omafra.gov.on.ca/english/stats/hort/veg_all13-14.htm

Teemusk, A., \& Mander, Ü. (2009). Greenroof potential to reduce temperature fluctuations of a roof membrane: A case study from Estonia. Building and Environment, 44(3), 643-650. http://dx.doi.org/10.1016/j.buildenv.2008.05.011

Tomalty, R., \& Komorowski, B. (2010). Curb appeal: New research explores ways to value green roofs by estimating their impact on property values. Living Architecture 
Monitor, 12(1), 26-27. $\quad$ Retrieved from http://www.greenroofs.org/resources/LAM_Winter_2010.pdf

United States Environmental Protection Agency. (2009). Green roofs for stormwater runoff control. Publication number (EPA/600/R-09/026). Edison, NJ: US. National Risk Management Research Laboratory. Retrieved from http://nepis.epa.gov/Adobe/PDF/P1003704.PDF

United State Geological Survey. (2014a). Nitrogen and water. Retrieved from http://water.usgs.gov/edu/nitrogen.html

United States Geological Survey (2014b). Phosphorus and water. Retrieved from http://water.usgs.gov/edu/phosphorus.html

VanWoert, N.D., Rowe, D.B., Andresen, J.A., Rugh, C.L., Fernandez, R.T., \& Xiao, L. (2005a). Green roof stormwater retention: Effects of roof surface, slope, and media depth. Journal of Environmental Quality, 34(3), 1036.

VanWoert, N.D, Rowe, D.B., Andresen, J.A., Rugh, C.L., \& Xiao, L. (2005b). Watering regime and green roof substrate design affect sedum plant growth. HortScience, 40(3), 659-664. doi: 10.1007/s11252-008-0052-0

Veisten, K., Smyrnova, Y., Klaeboe, R., Hornikx, M., Mosslemi, M., \& Kang, J. (2012). Valuation of green walls and green roofs as soundscape measures: Including monetised amenity values together with noise-attenuation values in a cost-benefit analysis of a green wall affecting courtyards. International Journal of Environmental Research and Public Health, 9, 3770-3788. doi:10.3390/ijerph9113770

Vina, A., Gitelson, A.A., Nguy-Robertson, A.L., \& Peng. Y. (2011). Comparison of different vegetation indices for the remote assessment of green leaf area index of crops. Remote Sensing of Environment, 115, 3468-3478. doi:10.1016/j.rse.2011.08.010

Whittinghill, L.J. \& Rowe, D.B. (2012). The role of green roof technology in urban agriculture. Renewable Agriculture \& Food Systems, 27(4), 314-322. doi:http://dx.doi.org.ezproxy.lib.ryerson.ca/10.1017/S174217051100038X

Whittinghill, L.J., Rowe, D.B, \& Cregg, B.M. (2013). Evaluation of vegetable production on extensive green roofs. Agroecology and Sustainable Food Systems, 37, 465-484. doi:10.1080/21683565.2012.756847

Wong, N.H., Tan, P.Y., \& Chen, Y. (2007). Study of thermal performance of extensive rooftop greenery systems in the tropical climate. Building and Environment, 42(1), 25-54. doi: 10.1016/j.buildenv.2005.07.030

Wong, N.H., Tay, S.F., Wong, R., Ong, C.L., \& Sia, A. (2003). Life cycle cost analysis of rooftop gardens in Singapore. Building and Environment, 38(3), 499-509. doi: 10.1016/S0360-1323(02)00131-2 


\section{Appendix A: Keywords/Search Terms}

\begin{tabular}{|c|c|}
\hline Keywords/Terms & Modifiers \\
\hline Intensive green roof & aesthetic \\
\hline Extensive green roof & air quality \\
\hline Green roof agriculture & amenity \\
\hline \multirow[t]{19}{*}{ Green roof } & cost \\
\hline & economic value \\
\hline & fertilizer \\
\hline & heat transfer \\
\hline & irrigation \\
\hline & irrigation \\
\hline & leaf area index \\
\hline & runoff quality \\
\hline & runoff quantity \\
\hline & soil \\
\hline & substrate \\
\hline & urban agriculture \\
\hline & urban heat island \\
\hline & valuation \\
\hline & value \\
\hline & value \\
\hline & water quality \\
\hline & water quantity \\
\hline & watering \\
\hline
\end{tabular}




\section{Appendix B: Literature Review Table}

\begin{tabular}{|c|c|c|c|c|c|c|c|c|c|c|c|c|}
\hline Authors & Year & WRQuan & WRQual & & Urban H. I. & Heat Tran. & Maint. & Cost & Air Qual & Amenity & & Irrigation \\
\hline Akbari, Pomerantz, Taha & 2001 & & 0 & 0 & 1 & 1 & & 0 & 0 & 0 & 0 & 0 \\
\hline Banting, Doshi, Li, Missios & 2005 & & 1 & 1 & 1 & 1 & & 0 & 1 & 1 & 0 & 0 \\
\hline Bass, Baskaran & 2001 & & 1 & 0 & 1 & 1 & & 0 & 0 & 0 & 0 & 0 \\
\hline Berndtsson & 2010 & & 1 & 1 & 0 & 0 & & 0 & 0 & 0 & 0 & 0 \\
\hline Berndtsson, Bengtsson, Jir & 2009 & & 0 & 1 & 0 & 0 & & 0 & 0 & 0 & 0 & 0 \\
\hline Berndtsson, Emilsson, Ben & 2006 & & 0 & 1 & 0 & 0 & & 0 & 0 & 0 & 0 & 0 \\
\hline Bianchini, Hewage & 2012 & & 1 & 0 & 1 & 1 & & 1 & 1 & 1 & 1 & 0 \\
\hline Blanusa, Monteiro, Fantoz & 2013 & & 0 & 0 & 0 & 1 & & 0 & 0 & 0 & 0 & 0 \\
\hline Carter, Jackson & 2006 & & 1 & 0 & 0 & 0 & & 0 & 0 & 0 & 0 & 0 \\
\hline Cohnstaedt, Shields, Mac[ & 2003 & & 0 & 0 & 0 & 0 & & 0 & 0 & 0 & 1 & 0 \\
\hline Coutts, Daly, Beringer, Tak & 2013 & & 0 & 0 & 1 & 1 & & 0 & 0 & 0 & 0 & 0 \\
\hline Emilsson, Berndtsson, Ma & 2007 & & 0 & 1 & 0 & 0 & & 0 & 0 & 0 & 0 & 0 \\
\hline Gagliano, Detommaso, No & 2015 & & 0 & 0 & 1 & 1 & & 0 & 0 & 0 & 0 & 0 \\
\hline Getter, Rowe & 2006 & & 1 & 1 & 1 & 1 & & 1 & 0 & 1 & 1 & 1 \\
\hline Getter, Rowe, Andresen & 2007 & & 1 & 0 & 0 & 0 & & 0 & 0 & 0 & 0 & 0 \\
\hline Getter, Rowe, Robertson, & 2009 & & 0 & 0 & 0 & 0 & & 0 & 0 & 1 & 0 & 0 \\
\hline Guo, Zhang, Liu & 2014 & & 1 & 0 & 0 & 0 & & 0 & 0 & 0 & 0 & 1 \\
\hline Ichihara, Cohen & 2010 & & 0 & 0 & 0 & 0 & & 0 & 0 & 0 & 1 & 0 \\
\hline Kohler, Schmidt, Grimme, & 2002 & & 1 & 1 & 0 & 1 & & 0 & 0 & 0 & 0 & 0 \\
\hline Lee, Williams, Sargent, Far & 2014 & & 0 & 0 & 0 & 0 & & 0 & 0 & 0 & 1 & 0 \\
\hline Mentens, Raes, Hermy & 2006 & & 1 & 0 & 0 & 0 & & 0 & 0 & 0 & 0 & 0 \\
\hline Molineux, Fentiman, Gang & 2009 & & 1 & 1 & 0 & 0 & & 0 & 0 & 0 & 0 & 0 \\
\hline Monterusso, Rowe, Rugh & 2005 & & 0 & 0 & 0 & 0 & & 0 & 0 & 0 & 0 & 1 \\
\hline Niachou, Papakonstantino & 2001 & & 0 & 0 & 0 & 1 & & 0 & 0 & 0 & 0 & 0 \\
\hline Oberndorfer, Lundholm, B & 2007 & & 1 & 0 & 1 & 0 & & 0 & 1 & 0 & 0 & 1 \\
\hline Onmura, Matsumoto, Hok & 2000 & & 0 & 0 & 0 & 1 & & 0 & 0 & 0 & 0 & 0 \\
\hline Proksch & 2011 & & 0 & 0 & 0 & 1 & & 1 & 0 & 0 & 0 & 1 \\
\hline Razzaghmanesh \& Beecha & 2014 & & 1 & 0 & 0 & 0 & & 0 & 0 & 0 & 0 & 0 \\
\hline Rowe & 2011 & & 1 & 1 & 0 & 0 & & 0 & 0 & 1 & 0 & 0 \\
\hline Rowe, Kolp, Greer, \& Gett & 2014 & & 1 & 0 & 0 & 0 & & 0 & 1 & 0 & 0 & 1 \\
\hline Simmons, Gardiner, Windl & 2008 & & 1 & 0 & 0 & 1 & & 0 & 0 & 0 & 0 & 0 \\
\hline Speak, Rothwell, Lindey, S & 2013 & & 1 & 0 & 0 & 0 & & 0 & 0 & 0 & 0 & 0 \\
\hline Takebayashi, Moriyama & 2007 & & 0 & 0 & 0 & 1 & & 0 & 0 & 0 & 0 & 0 \\
\hline Teemusk, Mander & 2009 & & 0 & 0 & 0 & 1 & & 0 & 0 & 0 & 0 & 0 \\
\hline Tomalty, Komorowski & 2010 & & 0 & 0 & 0 & 0 & & 0 & 0 & 0 & 1 & 0 \\
\hline VanWoert, Rowe, Andrese & 2005 & & 1 & 0 & 0 & 0 & & 0 & 0 & 0 & 0 & 0 \\
\hline VanWoert, Rowe, Andrese & 2005 & & 0 & 0 & 0 & 0 & & 0 & 0 & 0 & 0 & 1 \\
\hline Veisten, Smyrnova, Klæbo & 2012 & & 0 & 0 & 0 & 0 & & 1 & 1 & 0 & 1 & 0 \\
\hline Virk, Jansz, Mavrogianni, N & 2015 & & 0 & 0 & 1 & 1 & & 0 & 0 & 0 & 0 & 1 \\
\hline Whittinghil \& Rowe & 2012 & & 0 & 1 & 0 & 0 & & 0 & 1 & 0 & 0 & 1 \\
\hline Whittinghill, Rowe, Cregg & 2013 & & 0 & 0 & 0 & 0 & & 0 & 0 & 0 & 1 & 0 \\
\hline Wong, Tan, Chen & 2005 & & 0 & 0 & 0 & 1 & & 0 & 0 & 0 & 0 & 0 \\
\hline Wong, Tay, Wong, Ong, Si: & 2003 & & 0 & 0 & 0 & 1 & & 1 & 1 & 0 & 1 & 0 \\
\hline & Total & & 18 & 9 & 8 & 15 & & 3 & 4 & 5 & 6 & 7 \\
\hline
\end{tabular}




\section{Appendix C: User Manual}

1. All fields that require user input are denoted with a dark green color. When using the tool, only these fields need be manipulated.

2. Work from the leftmost column to the right. Criteria Weighting should be manipulated first, then Variable Weighting, and finally Selection.

3. At the bottom of the column labeled Criteria Weighting, there is a red box titled Remaining Weighting Points. Split up the 100 points between the 5 criteria based on your project's goals. When the Remaining Weighting Points box shows 0 points remaining, move to the next step.

4. Two criteria, Water Runoff Quality and Amenity require further point breakdown, which is completed in the Variable Weighting column. As with Criteria Weighting, 100 points must be distributed between each of the variables that make up each criterion. When both Remaining Weighting Points boxes in this column show 0 points remaining, move to the next step.

5. Examine the design options in the salmon/pale orange boxes in the center of the tool. These are the options that have been directly evaluated for use in the tool. If the design option planned for use in the user's project is not shown, select the most similar option, in terms of performance. This may require additional research on the part of the designer to ensure that their selected option is a valid representation of the design that will be used.

6. The dark purple column on the far right of the table displays the weighted points achieved for each category, based on the user's weightings chosen in Steps 3 and 4. This demonstrates to the user how successful their choices are at meeting the goals of each criterion.

7. The dark orange box at the table's bottom right shows an additive point total, displaying the overall effectiveness of the project as planned. The maximum achievable point value is 5 .

8. If evaluating multiple design options for one project, Criteria Weighting and Variable Weighting values are not changed from one option to the next, since the projebi ct's goals are not changing. Leave these values constant, instead adjusting the Selection column to build different scenarios. 